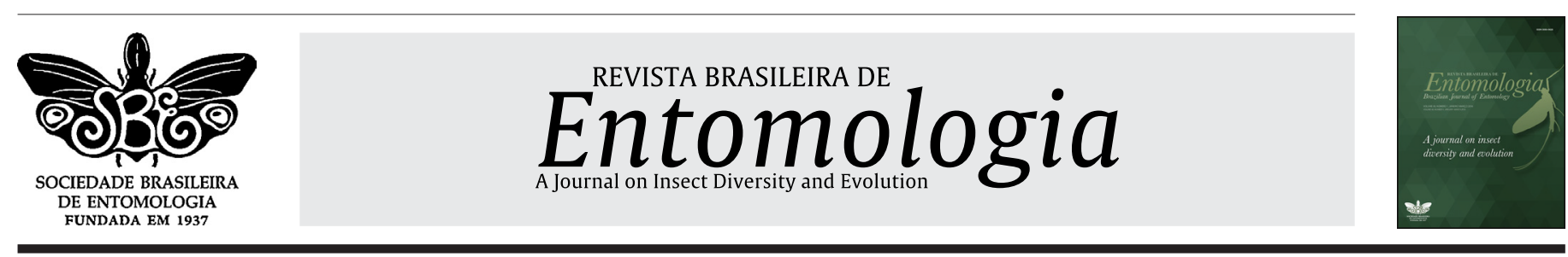

\title{
Blood-feeding behavior of Anopheles species (Diptera: Culicidae) in the district of Ilha de Santana, state of Amapá, eastern Brazilian Amazon
}

\author{
Ledayane Mayana Costa Barbosa ${ }^{1,2^{*}}$ (D), Vera Margarete Scarpassa² (D) \\ ${ }^{1}$ Universidade Federal do Amapá, Departamento de Ciências Biológicas e da Saúde, Laboratório de Arthropoda, Macapá, AP, Brasil. \\ 2Instituto Nacional de Pesquisas da Amazônia, Coordenação de Biodiversidade, Laboratório de Genética de Populações e Evolução de \\ Mosquitos Vetores de Malária e Dengue, Manaus, AM, Brasil.
}

\section{A R T I C L E I N F O}

\section{Article history:}

Received 21 May 2020

Accepted 08 November 2021

Available online 06 December 2021

Associate Editor: Leonardo Chaves

\section{Keywords:}

Behavioral patterns

Entomological parameters

Malaria

\begin{abstract}
A B S T R A C T
The present study aimed identifying the behavioral patterns of Anopheles species as well as to estimate the parity rate and natural infection analysis for Plasmodium species in the district of Ilha de Santana, state of Amapá, Brazil. The samples were obtained in four and 12-hours collections. In the intradomiciliary and peridomiciliary conditions and also in environments with the presence of animals from January/2017 to December/2018. The entomological parameters evaluated were human biting rate (HBR); Indexes of Anthropophily $\left(\mathrm{I}_{A}\right)$ and Zoophily $\left(\mathrm{I}_{z}\right)$; Parity Rate (PR); Natural Infection Rate (NIR); Monthly and annual entomological inoculation rate (EIR). A total of 1,330 Anopheles specimens were collected, distributed in nine species. All captured species showed preference biting in outdoor enviroment. Anopheles darlingi was the most frequent species collected in indoor environment and the most anthropophilic $\left(\mathrm{I}_{\mathrm{A}}=0.39\right)$ compared with the remaining species captured. It was also the unique species positive for Plasmodium vivax, had the highest anthropophily degree, highest biting activity and HBR in the first hours with a hight rate of parous females. Anopheles nuneztovari s.l. was the most zoophilic species $\left(\mathrm{I}_{z}=0.65\right)$. These findings suggest that $A$. darlingi is the main malaria vector in the studied area. Anopheles albitarsis s.l. was the second species more anthropophilic $\left(\mathrm{I}_{\mathrm{A}}=0.31\right)$ and revealed a stable pattern with a biting activity peak after sunset, consequently this species may contribute with malaria transmission in area.
\end{abstract}

\section{Introduction}

Malaria transmission in South America occurs in all Amazonian countries (Brazil, Bolivia, Peru, Ecuador, Colombia, Venezuela, Guyana, Suriname and French Guiana) (MS, 2020a). In Brazil, approximately 68 species of Anopheles Meigen, 1818 have already been reported, of which approximately 33 occur in the Brazilian Amazon, and 23 species have already been reported in the state of Amapá (Deane et al., 1948; Deane et al., 1971; Bergo et al., 2007; Galardo et al., 2015; Barbosa et al., 2016; WRBU, 2020). These species are distributed in five subgenera, with the ones with the greatest epidemiological importance in the subgenera Kerteszia Theobald, 1905 and Nyssorhynchus Blanchard, 1902 (Hiwat and Bretas, 2011). The latter includes the main species involved in the transmission of human malaria in the Brazilian Amazon region, including Anopheles darlingi Root, 1926 and some members of the Albitarsis and Nuneztovari complexes (Hiwat and Bretas, 2011).

Anopheles darlingi is the main vector of Plasmodium species that cause the human malaria in the Brazilian Amazon, with broad behavioral plasticity (ranged from endophilic to exophilic and ranged from anthropophilic to zoophilic), increasing the complexity of the

\footnotetext{
*Corresponding author.

E-mail: barbosalmc@unifap.br (L.M.C. Barbosa).
}

transmission dynamics of this disease (Santos et al., 2009). The degree of anthropophily is an essential condition for anopheline species to be considered an important vector of human malaria (Gouveia de Almeida, 2011) and, within the same taxon, the degree of anthropophyly may vary according to the region (Forattini, 2002).

Variations in the behavioral patterns of anopheline species are influenced by external factors, such as ecological, environmental, and demographic. Human actions can also exert selective pressure on vector populations, benefiting them under new conditions (Kuwabara, 2008). For example, the deforestation and anthropization influence the local density of $A$. darlingi, which show high adaptive plasticity and degree of synanthropism (Vittor et al., 2006; Gomes et al., 2008). In addition, behavioral changes from endophily to exophily, resulted from the use of indoor residual spraying (IRS), are the selection of vector behavior and/or physiological resistance to insecticides (Tadei, 1987; Glunt et al., 2015; Ranson and Lissenden, 2016; Prussing et al., 2018).

Behavioral and ecological patterns of anopheline vectors can vary in space and time, including seasonal changes. Thus, local control strategies must be adequately planned according to the characteristics of the vectors (MS, 2019a). Periodic studies evaluating behavioral 
patterns determined by the species composition of each area, density, interspecific interactions, biting behavior, intensity of human contact and female longevity are essential to monitor changes that may be associated with climate and environmental determinants (Barbosa et al., 2016; MS, 2019a).

The behavior of the species involved in malaria transmission influences the local epidemiological pattern (Barbosa et al., 2016). The same population may show behavioral variations due to external changes, increasing the complexity of the disease transmission dynamics, as have been observed in A. darlingi populations (Voorham, 2002; Santos et al., 2009). Economic development, exploitation of forest products and migratory flow have driven the decrease in forest cover in the Brazilian Amazon. Deforestation is an important risk factor for the emergence of malaria transmission (Tadei et al., 1998; Chaves et al., 2018). These changes affect the development and proliferation of mosquitoes, in addition to socioeconomic factors associated with low Human Development Index (HDI) (migration, housing, population density, and income), as well as environmental (hydrology, climate, topography, and vegetation), biological (life cycle of vectors and pathogens and population immunity) and medical-sanitary components (health system effectiveness) (PAHO, 2009; Tadei et al., 2017; Silva et al., 2010). Despite advances in treatments with new drugs and attempts to develop vaccines, strategies to combat vectors, as well as land use and development planning are still lacking (Li et al., 2016; WHO, 2017; Chaves et al., 2018).

In 2019, an estimated 229 million malaria cases occurred worldwide and approximately 139 million people are at risk of contracting the disease in the Americas (WHO, 2020). In the Americas, Brazil, Colombia, and Venezuela combined account for $86 \%$ of the estimated cases of malaria. In Brazil, approximately $99.8 \%$ of them occur in the Amazonian region and the states with most malaria cases are: Acre, Amazonas, Amapá, Pará, Rondônia, and Roraima (WHO, 2020; MS, 2020b). In 2018 alone, 194,512 malaria cases were reported in Brazil, of which 10,008 cases occurred in Amapá (MS, 2019b).

In the municipality of Santana, state of Amapá, 2,811 cases of malaria were reported in 2018, with an Annual Parasite Index (API) of 23.5. In the same year, 570 cases were reported in the district of Ilha de Santana, with an API of 241.3; thus, considered a high-risk area of malaria transmission (API $\geq 50$ ) (MS, 2019b).

The present study aimed identifying the behavioral patterns of Anopheles species as well as to estimate the parity rate and natural infection rate for Plasmodium species in the district of Ilha de Santana, state of Amapá, an area where occur malaria transmission.

\section{Materials and methods}

Specimens of Anopheles species were collected in the district of Ilha de Santana, municipality of Santana, state of Amapá, Brazil. This district is located on the banks of the Amazon River, between the geographical coordinates of $00^{\circ} 04^{\prime} 00^{\prime \prime}$ and $00^{\circ} 06^{\prime} 00^{\prime \prime} \mathrm{S}$ and $51^{\circ} 08^{\prime} 00^{\prime \prime}$ and $51^{\circ} 12^{\prime} 30^{\prime \prime} \mathrm{W}$, and comprises an area of $20.06 \mathrm{~km}^{2}$ with an estimated population of 3,226 inhabitants (Madeira and Simões, 1972; Valente et al., 1998; IBGE, 2020). The municipality of Santana has an area of $1,541,224 \mathrm{~km}^{2}$ and is located in the southern region of the state of Amapá, $25 \mathrm{~km}$ from the capital Macapá, bordering the municipalities of Macapá, Mazagão and Porto Grande (IBGE, 2013). The main economic activity of the district of Ilha de Santana is based on the primary sector, with most residents working in agricultural activities (fruits and vegetables) and in the production of fruit pulps, especially of two important products of the açaí palm (Euterpe oleracea Mart): fruits and palm hearts (Valente et al., 1998).
Adult anophelines were collected from January 2017 to December 2018, covering the rainy and dry seasons. Active collections were carried out using the Protected Human Attraction Technique (PHAT), with a team formed by six experienced and properly trained collectors for this purpose. All team members used Personal Protective Equipment - PPE's, in comply with safety guidelines on the basic material required for sampling activities of the "Guide for Planning Anopheline Sampling by the Protected Human as Attraction Technique (PHAT) and Monitoring Health Risks of the Professional Collector" (MS, 2019a). Anopheline specimens (females only) were collected with the aid of a flashlight, small insect collecting net, and a mouth aspirator, when trying to land on collectors, following Forattini et al. (1999).

The selection of sampling sites followed the criteria: (I) locations with the highest number of reports of malaria cases and (II) locations with the higher demographic density (IBGE, 2017). Sampling days were determined according to the lunar phases (Horsfall, 1943). Collections were carried out for four and 12 continuous hours and in habitats with the presence of animals (pigs, chickens, and/or cattle).

The collections were divided into three categories: the first one evaluated the levels of endophily and exophily. Collections were carried out concomitantly with one collector indoors (inside the dwelling - intradomiciliary) and another outdoors (within a radius of up to $\sim 30 \mathrm{~m}$ away from the dwelling - peridomiciliary) from 18:00 to 22:00 hours in three different dwellings on the same day. The second category had the main goal of evaluating human biting rate and hourly biting activity in the peridomiciliary area from 18:00 to 6:00 hours. Three collectors participated in these collections, taking turns every two hours. Finally, the third category assessed parameters of anthropophily and zoophily in environments with pigs, chickens and/or cattle (extradomiciliary area) and in the peridomiciliary area, with two collectors, one collector in each area simultaneously from 18:00 to 22:00 hours. The three categories totaled 52 collection sites (Fig. 1) (Table 1S, supplementary file).

All mosquitoes captured were placed in plastic cups and properly labelled with date, hour, site, and sampling method. Following Forattini (1962), mosquitoes were then transported in tightly closed isothermal boxes to the Laboratory of Arthropods of the Federal University of Amapá, where the morphological identification and dissection of ovaries were carried out to estimate parity rate. Anophelines were killed in a freezer at $-20^{\circ} \mathrm{C}$ and then identified under a stereo microscope Zeiss Stemi DV4, with the aid of dichotomous keys of Faran and Linthicum (1981), Consoli and Lourenço-de-Oliveira (1994), and Forattini (2002). The nomenclature used was proposed by Guimarães (1997). Damaged specimens that could not be identified were grouped as Anopheles species.

The collected individuals belonging to species complexes were subjected to molecular analysis to identify their members, using the DNA barcode region (Folmer region) of the COIgene of mitochondrial DNA (data no shown). From each species recognized as complex, a sample of $3 \%$ of the total captured was taken for analyzes. Other species were also sequenced to confirm their occurrence in the study area.

\section{Endophily and Exophily}

The four-hour collections carried out inside (indoors) the dwelling (intradomiciliary) and outdoors (peridomiciliary) were used to estimate the levels of endophily and exophily of the species. The variable level considered the number of mosquitoes (abundance) collected in each environment, analyzing the absolute and relative frequency. 


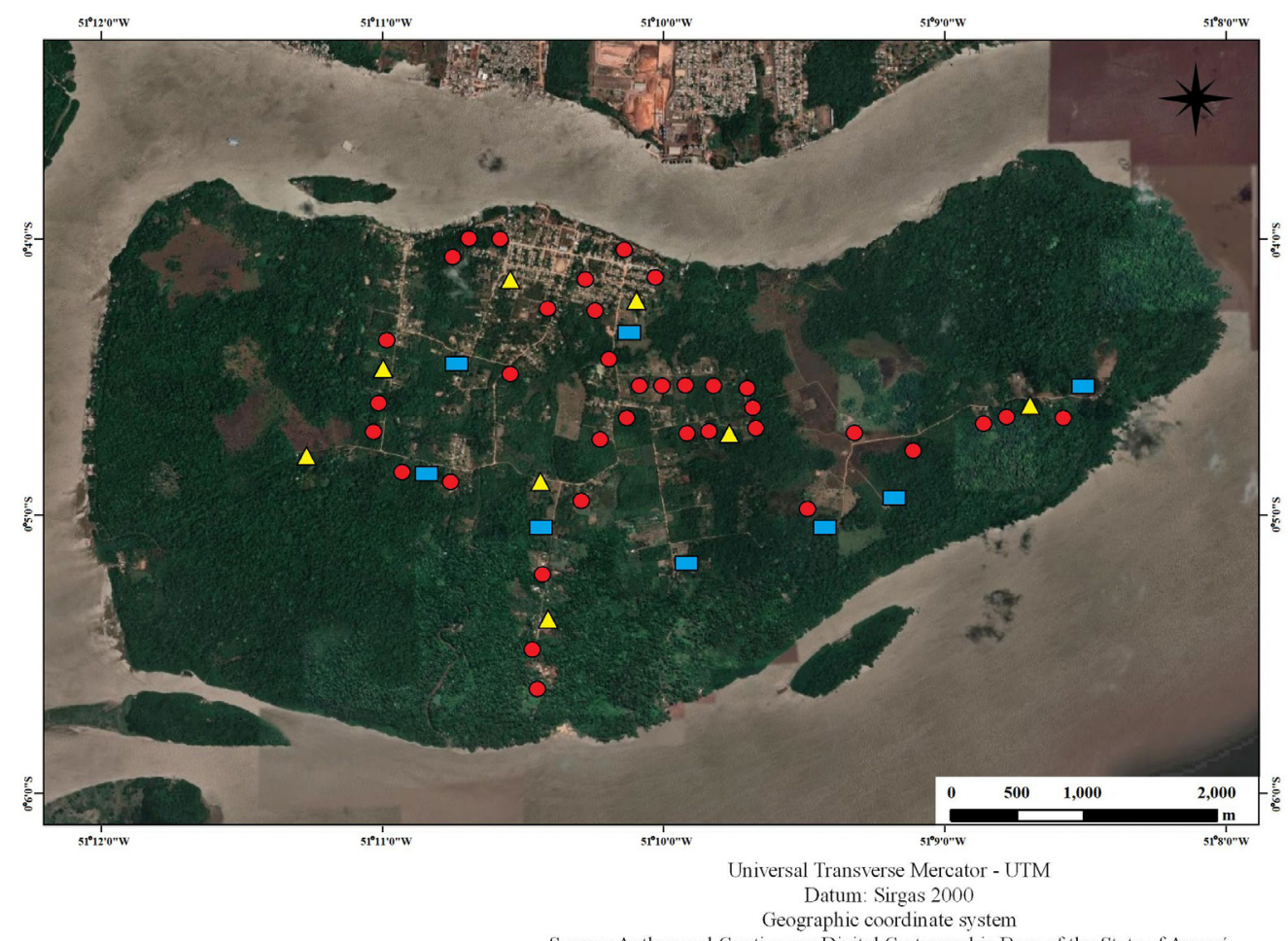

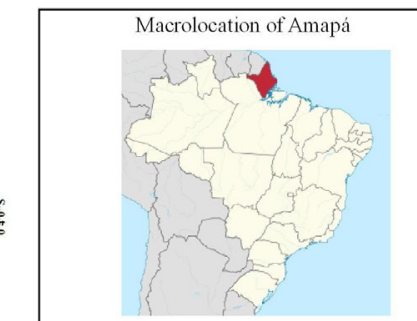

Macrolocation of the area of the study

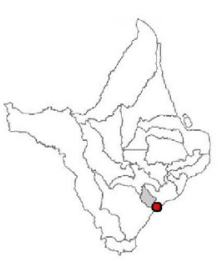

4-h collections (Intra./Peri.)

$\triangle$ 12-h collections (Peri.)

4-h collections (Human/Animals)

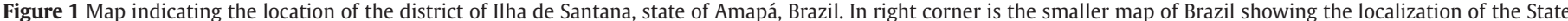

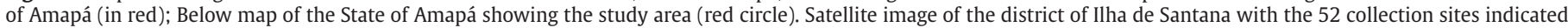
according to the three collection categories (For interpretation of the references to color in this figure legend).

\section{Anthropophily and Zoophily}

These parameters were evaluated using four-hour collections carried out specific for these analyses in the peridomiciliary area and in environments with the presence of animals (extradomiciliary area). The Index of Anthropophily $\left(I_{A}\right)$ was determined based on anophelines attracted by the collector seeking a blood meal, while the Index of Zoophily $\left(\mathrm{I}_{\mathrm{z}}\right)$ was obtained based on anophelines searching to feed on the blood of animals or resting close to them. These parameters were then compared by separately computing the species collected near humans and animals, as described by Tadei et al. (1993).

These parameters were calculated as follows: $\mathrm{I}_{A}=$ TNSD/OTSD; where: TNSD = total number of specimens collected in dwellings per species divided by OTSD = overall total number of specimens of all species collected in dwellings. $\mathrm{I}_{2}=$ TNSS/OTSS; where: TNSS = total number of specimens collected in sheds with animals per species divided by OTSS = overall total number of specimens of all species collected at the sheds.

\section{Human biting rate (HBR)}

Twelve-hour collections were carried out to examine the attraction of mosquitoes to humans. The index of attraction as mosquito/human/ hour was calculated, according to the formula: $\mathrm{HBR}=\mathrm{N} / \mathrm{NC} / \mathrm{CT}$, where: $\mathrm{N}$ = number of mosquitoes collected; $\mathrm{NC}=$ number of collectors; $\mathrm{CT}=$ collection time (Service, 1993).

\section{Hourly biting activity}

The time of highest activity and the hematophagic pattern of the species were analyzed using the data obtained from 12-hour collections.

\section{Parity rate}

All species and specimens captured during four and 12-hour collections were dissected. The abdomens were used for the dissection of ovaries for the analysis of parity rates, which were determined as nulliparous and parous based on the arrangement of tracheolar filaments, as described by Detinova (1962). After dissections, ovaries were examined under a Bel Photonics light microscope with 400x magnification. Parity rate (PR) was expressed according to the formula: $\mathrm{PR}=\mathrm{FP} \times 100 / \mathrm{FD}$; where: $\mathrm{FP}=$ number of parous females and $\mathrm{FD}=$ number of dissected females.

\section{Analysis of Plasmodium infection rate}

Analysis of Plasmodium species infection rate was performed only for the most frequent species of mosquitoes captured during four and 12-hour collections. After identification, the heads and thoraces of females of $A$. darlingi, Anopheles albitarsis s.l. Lynch-Arribálzaga, 1878, Anopheles braziliensis (Chagas, 1907) and Anopheles nuneztovari s.l. Gabaldón, 1940 were removed to estimate natural infection rates of Plasmodium species, which was detected by amplification of fragment of ribosomal DNA. The heads and thoraces were removed to refine the results and focus on the detection of sporozoites present in salivary glands, the infectious form of the parasite.

Head and thorax were placed in microtubes containing isopropanol, in pools by species, date, hour, site and collection method and preserved in freezer at $-20^{\circ} \mathrm{C}$. The pools contained up to five heads and thoraces per species. The material was then transported to the Laboratory of Population Genetics and Evolution of Malaria and Dengue Vectors of the Instituto Nacional de Pesquisas da Amazônia (INPA), in Manaus, where the samples were processed and analyzed. 
DNA extraction was performed following the protocol described by Sambrook and Russell (2001). PCR reactions were performed following the protocol described by Snounou et al. (1993), which consisted of a semi-nested-PCR and two reactions. The second reaction, which identifies the Plasmodium species, was carried out only when the first reaction was positive for the Plasmodium genus. The primer sequences used for the detection of Plasmodium species as well as for $P$. falciparum Welch, 1897, P. vivax Grassi and Feletti, 1890, and P. malariae Laveran, 1881 followed Snounou et al. (1993). The PCR reactions were carried out in a VERIT thermocycler, Applied Biosystems. As a positive control, a sample confirmed for $P$. vivax was used, while the negative control consisted of DNA of Anopheles konderi Galvão and Damasceno, 1942 females reared in the insectary of the Laboratory of Population Genetics and Evolution of Malaria and Dengue Vectors of the INPA, first generation.

After amplification, PCR products were analyzed on a $1 \%$ agarose gel, where $8 \mu \mathrm{L}$ of the amplified product and $2 \mu \mathrm{L}$ of the GelRed dye were loaded onto the gel. After electrophoresis, the gel was examined under ultraviolet light and photo-documented with an imaging system coupled in the photodocumentary apparatus, Loccus Biotecnologia, model L-Pix Touch. The sizes of the obtained fragments were compared with the 100-bp ladder DNA for the first reaction and Low DNA Mass for the second reaction (Invitrogen ${ }^{\circledR}$ ).

The detection rate of Plasmodium DNA was calculated using the minimum infection rate adapted from Forattini (2002), as MIR = N/I x 100; where: $\mathrm{N}=$ number of positive pools to the infection test; $\mathrm{I}=$ total number of tested mosquitoes of a species. The Entomological Inoculation Rate (EIR), which indicates the number of infective bites that a person can receive per unit of time, was calculated as: EIR = HBR x MIR; where: HBR = Human biting rate and MIR = minimum infection rate. For the monthly analysis of EIR, the product was multiplied by 31 (days) and for the annual analysis, the product was multiplied by 365 (days) (Williams and Pinto, 2012).

\section{Data analysis}

Means were used to compare endophily/exophily and anthropophily/ zoophily with the Student's $t$ test and the non-parametric substitute Mann-Whitney test, according to the data distribution.

The statistical analysis was based on the Generalized Linear Model (GLM) with the Poisson distribution. Poisson models were used to assess whether the target variable Anopheles abundance was influenced by the environment (intra and peridomiciliary), hematophagic activity time, and other species. Abundance was used as a response variable and environment (intra and peridomiciliary), species activity time, and species as predictor variable. GLM was also carried out to assess whether abundance was influenced by feeding preference (anthropophily and zoophily), species activity time, and other species. Considering abundance as a response variable and feeding preference (anthropophily and zoophily), species activity time and species as predictor variable. These analyzes were performed using the software R (R Core Team, 2021). The Kruskal-Wallis test was carried out to analyze HBR, hourly biting activity, and parity rate.

The most abundant species, especially the most frequent species indoor and outdoor environments were plotted in graphs with the number of specimens, by collection time intervals, combined with parity rate and number of malaria cases (data obtained from the Computerized Health System - Epidemiological Surveillance - SIVEP/MS). To test variable associations, Spearman correlations were used. Descriptive statistics were obtained with the software BioEstat version 5.0 (Ayres et al., 2007). The significance level of $\alpha=0.05$ was used.

\section{Results}

A total of 1,330 Anopheles specimens were collected in the study area, distributed in nine species and two subgenera: Nyssorhynchus (six species) and Anopheles (three species). The species $A$. konderi and Anopheles triannulatus Neiva and Pinto, 1922 were identified by molecular methods. For specimens belonging to the Albitarsis and Nuneztovari complexes, sequences of high quality could not be obtained, making comparisons with those deposited in GenBank impossible; therefore, in this study, the specimens were denominated as $A$. albitarsis s.l. and $A$. nuneztovari s.l., respectively. The sequenced specimens of $A$. braziliensis, A. darlingi, and Anopheles intermedius (Peryassú, 1908) confirmed the occurrence of these species in the study area. Of the total, 276 (20.75\%) were captured in four-hour collections (intradomiciliary and peridomiciliary), $169(12.71 \%)$ in the 12-hour collections (only peridomiciliary), and 885 (66.54\%) in four-hour collections (humans and animals), totaling 272 hours of sampling effort (Table 1).

Considering all sampling methods, $A$. nuneztovaris.l. was the most common captured species (45.26\%) in the area and with $83.53 \%$ of the specimens collected when evaluating anthropophilic and zoophilic indexes. The second most abundant species was A. darlingi (19.10\%), followed by $A$. albitarsis s.l. (18.57\%), and A. braziliensis (10.00\%) (Table 1).

Table 1

Species of Anopheles and absolute and relative frequency, according to the collection categories in the district of Ilha de Santana, municipality of Santana, state of Amapá (Kruskal-Wallis test $[13]=1.02 ; p>0.05$ ).

\begin{tabular}{|c|c|c|c|c|c|c|c|}
\hline \multirow{2}{*}{ Species } & \multicolumn{2}{|c|}{ 4-h collections (Intra./Peri.) } & \multicolumn{2}{|c|}{ 12-h collections (Peri.) } & \multicolumn{2}{|c|}{ 4-h collections (Humans/Animals) } & \multirow{2}{*}{ Total (\%) } \\
\hline & $\mathrm{n}^{\circ}$ & $\%$ & $\mathrm{n}^{\circ}$ & $\%$ & $\mathrm{n}^{\circ}$ & $\%$ & \\
\hline Anopheles (Ny.) albitarsis s.l. & 42 & 17.00 & 29 & 11.74 & 176 & 71.26 & $247(18.57)$ \\
\hline Anopheles (Ny.) braziliensis & 47 & 35.34 & 20 & 15.04 & 66 & 49.62 & $133(10.00)$ \\
\hline Anopheles (Ny.) darlingi & 100 & 39.37 & 44 & 17.32 & 110 & 43.31 & $254(19.10)$ \\
\hline Anopheles (An.) intermedius & 21 & 61.76 & 7 & 20.59 & 6 & 17.65 & $34(2.56)$ \\
\hline Anopheles (Ny.) konderi & 2 & 40.00 & 1 & 20.00 & 2 & 40.00 & $5(0.37)$ \\
\hline Anopheles (An.) mattogrossensis & 1 & 25.00 & 2 & 50.00 & 1 & 25.00 & $4(0.30)$ \\
\hline Anopheles (Ny.) nuneztovari s.l. & 44 & 7.31 & 56 & 9.32 & 502 & 83.53 & $602(45.26)$ \\
\hline Anopheles (An.) peryassui & 6 & 60.00 & 1 & 10.00 & 3 & 30.00 & $10(0.75)$ \\
\hline Anopheles (Ny.) triannulatus & 13 & 36.11 & 9 & 25.00 & 14 & 38.89 & $36(2.71)$ \\
\hline Anopheles spp. & - & - & - & - & 5 & 100.00 & $5(0.38)$ \\
\hline Total (\%) & 276 & 20.75 & 169 & 12.71 & 885 & 66.54 & $1,330(100.00)$ \\
\hline
\end{tabular}




\section{Behavioral patterns}

\section{Endophily and Exophily}

All species were captured more frequently in outdoor environment (76.45\%). Anopheles mattogrossensis Lutz and Neiva, 1911, A. konderi, Anopheles peryassui Dyar and Knab, 1908 and A. triannulatus were collected in low frequencies (lower than 5\%) (Table 2).

The levels of endophily and exophily observed for Anopheles species during the sampling period did not reveal significant differences between environments (Mann-Whitney $U$ test $=24 ; \mathrm{z}=-1.42 ; p=0.16$ ), although a predominance for the outdoor environment has been observed. Only one exception was recorded, represented by only one individual ( $A$. darlingi), which was collected in the indoor environment in May/2017. In the months of January and July 2017, no individuals were collected in the indoor environment.

Fig. 2 shows the levels of endophily and exophily for $A$. albitarsis s.l., A. braziliensis, A. darlingi, and $A$. nuneztovaris.l. Despite of predominance in outdoor environment, $A$. darlingi was the species that had the highest number of specimens collected in the indoor environment. Anopheles albitarsis s.l. was also captured in indoor environment in March/2017, July/2018, September/2018, and November/2018. The behavioral patterns of A. braziliensis and $A$. nuneztovaris.l. varied considerably during the sampling period. However, a significant difference between the two environments

Table 2

Anopheles species collected indoors (endophily) and outdoors (exophily), and peridomiciliary area (anthropophily) and in environments with the presence of animals

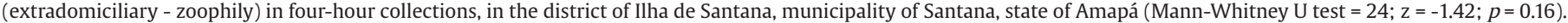

\begin{tabular}{|c|c|c|c|c|c|c|c|c|}
\hline \multirow{3}{*}{ Species } & \multicolumn{3}{|c|}{ Endophily and Exophily } & \multicolumn{5}{|c|}{ Anthropophily and Zoophily } \\
\hline & Intra. & Perid. & & Human & Animals & & & \\
\hline & $\begin{array}{l}\text { Individuals } \\
\text { number (\%) }\end{array}$ & $\begin{array}{l}\text { Individuals } \\
\text { number (\%) }\end{array}$ & Total (\%) & $\begin{array}{l}\text { Individuals } \\
\text { number (\%) }\end{array}$ & $\begin{array}{l}\text { Individuals } \\
\text { number (\%) }\end{array}$ & Total (\%) & $\mathrm{I}_{\mathrm{A}}$ & $\mathrm{I}_{\mathrm{z}}$ \\
\hline A. (Ny.) albitarsis s.l. & $6(14.29)$ & $36(85.71)$ & $42(15.22)$ & $37(21.02)$ & $139(78.98)$ & $176(19.89)$ & 0.31 & 0.18 \\
\hline A. (Ny.) braziliensis & $11(23.40)$ & $36(76.60)$ & $47(17.03)$ & $23(34.85)$ & $43(65.15)$ & $66(7.46)$ & 0.19 & 0.06 \\
\hline A. (Ny.) darlingi & $26(26.00)$ & $74(74.00)$ & $100(36.23)$ & $46(41.82)$ & $64(58.18)$ & $110(12.43)$ & 0.39 & 0.08 \\
\hline A. (An.) intermedius & $5(23.81)$ & $16(76.19)$ & $21(7.61)$ & $1(16.67)$ & $5(83.33)$ & $6(0.68)$ & 0.01 & 0.01 \\
\hline A. (Ny.) konderi & $1(50.00)$ & $1(50.00)$ & $2(0.73)$ & - & $2(100.00)$ & $2(0.23)$ & & \\
\hline A. (An.) mattogrossensis & - & $1(100.00)$ & $1(0.36)$ & $1(100.00)$ & - & $1(0.11)$ & 0.01 & 0.00 \\
\hline A. (Ny.) nuneztovari s.l. & $11(25.00)$ & $33(75.00)$ & $44(15.94)$ & 7 (1.39) & 495 (98.61) & $502(56.72)$ & 0.06 & 0.65 \\
\hline A. (An.) peryassui & $2(33.33)$ & $4(66.67)$ & $6(2.17)$ & $3(100.00)$ & - & $3(0.34)$ & 0.03 & 0.00 \\
\hline A. (Ny.) triannulatus & $3(23.08)$ & $10(76.92)$ & $13(4.71)$ & $1(7.14)$ & $13(92.86)$ & $14(1.58)$ & 0.01 & 0.02 \\
\hline Anopheles spp. & - & - & - & - & $5(100.00)$ & $5(0.56)$ & - & - \\
\hline Total (\%) & $65(23.55)$ & $211(76.45)$ & $276(100.00)$ & 119 (13.45) & $766(86.55)$ & $885(100.00)$ & & \\
\hline
\end{tabular}

$\mathrm{I}_{\mathrm{A}}=$ Index of Anthropophily; $\mathrm{I}_{\mathrm{Z}}=$ Index of Zoophily.

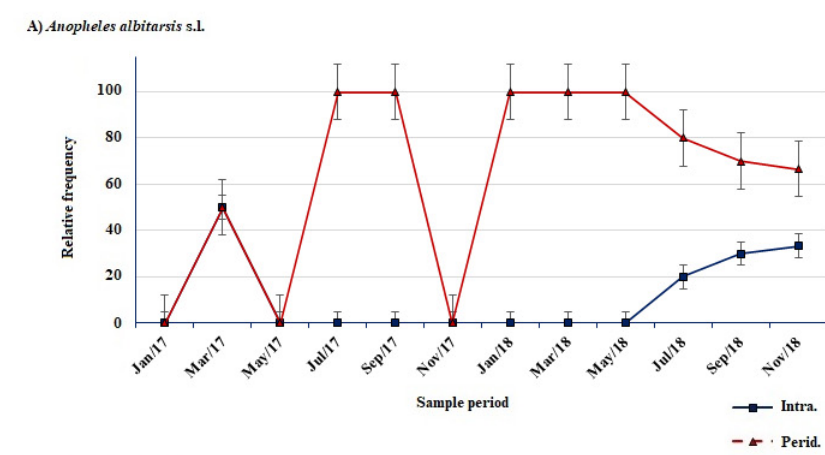

C) Anopheles darlingi

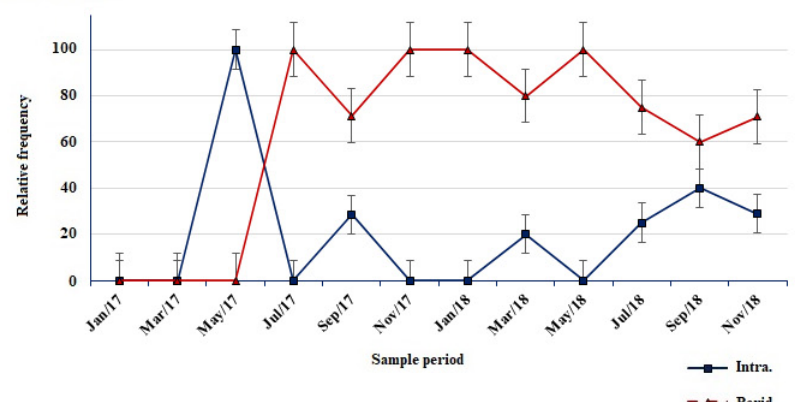

B) Anopheles braziliensis

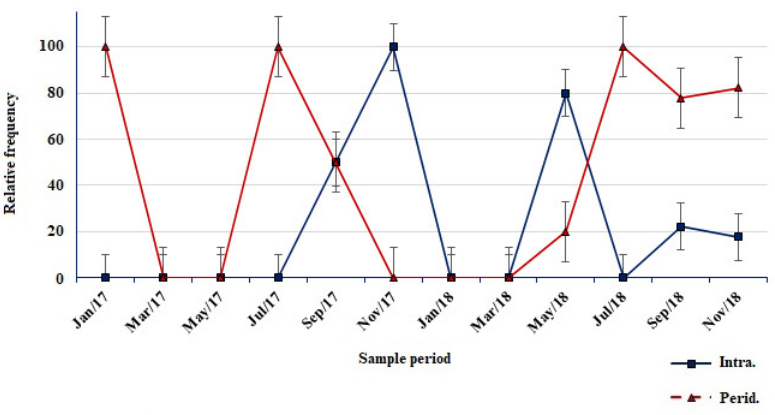

D) Anopheles munestovari s.l.

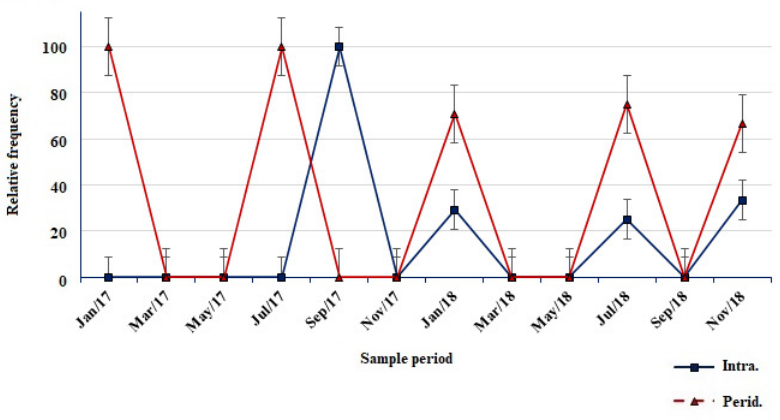

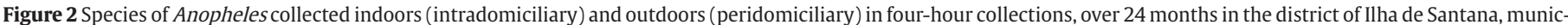

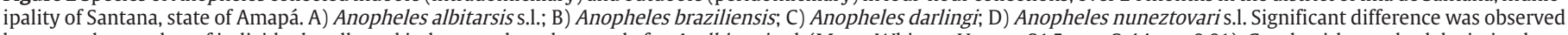

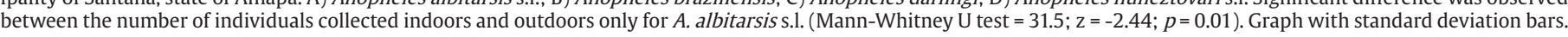


was observed only for the abundance of $A$. albitarsis s.l. throughout the sampling period (Mann-Whitney U test $=31.5 ; \mathrm{z}=-2.44 ; p=0.01$ ).

Regarding the collection time interval for the more frequent species collected, A. albitarsis s.l., A. braziliensis, A. darlingi and A. nuneztovari s.l. showed greater abundance in the second time interval (Fig. 3). A significant difference between indoor and outdoor environments was found for $A$. albitarsis s.l. and $A$. braziliensis when analyzing by time interval, indicating that the number of mosquitoes biting outdoors is significantly higher than that of those biting indoors (Student's $t$ test [3] $=-3.44 ; p=0.01$, Student's $t$ test [3] $=-2.49 ; p=0.04$; respectively).

GLM revealed that species abundance varied between intra and peridomiciliary environments, indicating the exophilic preference of Anopheles species, reflected in a very significant and positive relationship. Regarding abundance during collection times, a significant and negative relationship was observed, showing that anopheline activity was highest in the second collecting period. Another aspect analyzed was the general abundance of Anopheles species in relation to the abundance of the four most frequently collected species. A statistically significant and positive relationship was also found, showing that these species (A. albitarsis s.l., A. braziliensis, A. darlingi, and A. nuneztovari s.l.) occur in greater abundance in the district of Ilha de Santana (Table 3).

\section{Anthropophily and Zoophily Indexes}

Regarding anthropophilic and zoophilic indexes, the 885 mosquitoes collected were distributed in nine species. Highest abundance was observed in February/2017, with 346 (39.10\%) individuals, followed by February/2018, with 260 (29.38\%) specimens (mainly A. nuneztovaris.l. and A. albitarsis s.l.). The lowest abundance was observed in November/2017, with four (0.45\%) individuals ( $A$. albitarsiss.l. and $A$. darlingI). In all months, specimens were predominantly collected displaying zoophilic behavior, with the exception of November/2017 that showed two specimens (A. albitarsis s.l. and $A$. darlingi) collected in anthropophilic conditions and two in zoophilic conditions ( $A$. albitarsis s.l.). In May/2018, 28 specimens were collected near dwellings and only one specimen ( $A$. intermedius) was captured in the environment with animals. All species were more frequently collected displaying zoophilic behavior, except for $A$. mattogrossensis and $A$. peryassui with one $(0.11 \%)$ and three $(0.34 \%)$ individuals collected, respectively, displaying anthropophilic tendencies. Anopheles nuneztovari s.l. was the most abundant species, with 502 (56.72\%) specimens collected predominantly in the environment with animals. Of these, only

\section{Table 3}

Parameters and $p$ values estimated with a Generalized Linear Model with Poisson distribution explaining the absolute abundance of Anopheles obtained during two years of collections in the district of Ilha de Santana, Amapá, Brazil. The predictor variables were: environment (intra/peridomiciliary), species activity time, and the four species collected in greater abundance. A Poisson distribution GLM was also performed explaining the absolute abundance of Anopheles. The predictor variables were: feeding preference (anthropophily/zoophily), species activity time, and the four species collected in greater abundance.

\begin{tabular}{lccc}
\hline & Estimate & $p$-value & \\
\hline (Intercept) & 3.5607 & 0.00753 & $* *$ \\
Environment (intra/peridomiciliary) & 7.6928 & $<2 \mathrm{e}-16$ & ${ }^{* * *}$ \\
Time & -0.9248 & 0.00570 & $* *$ \\
Species $^{2}$ & 0.8744 & 0.00878 & $* *$ \\
\hline & Estimate & $p$-value & \\
\hline (Intercept) $_{\text {Feeding preference (anthropophily/zoophily) }}^{* *}$ & 0.24924 & 0.125722 & \\
Time & 1.88061 & $<2 \mathrm{e}-16$ & $* * *$ \\
Species $^{2}$ & 0.10241 & 0.000865 & $* * *$ \\
\hline
\end{tabular}

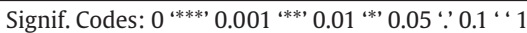

${ }^{2}$ Diference in abundance among the four main species collected: $A$. albitarsis s.l., $A$. braziliensis, A. darlingi and A. nuneztovari s.l.

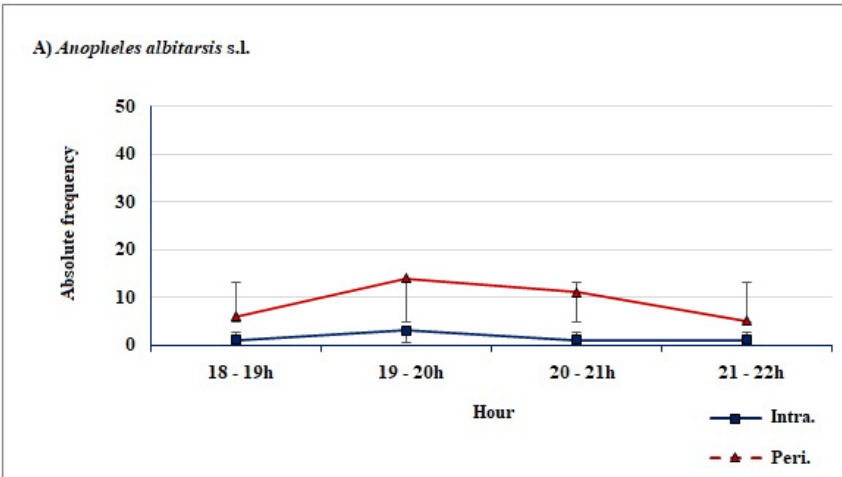

C) Anopheles darlingi

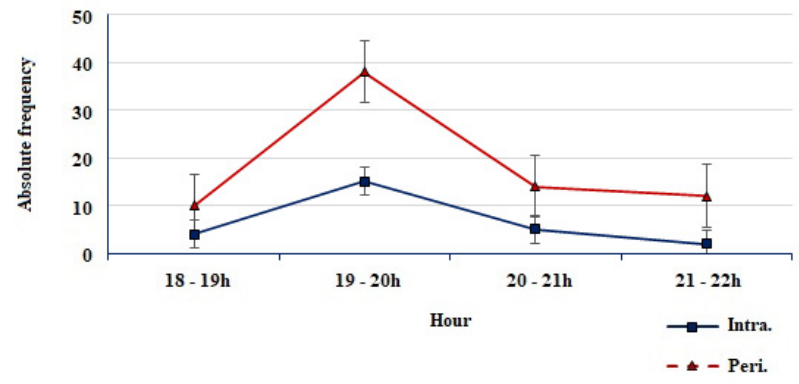

B) Anopheles braziliensis

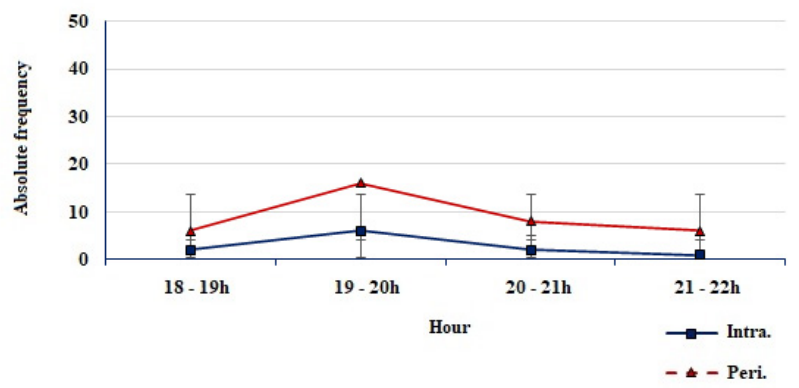

D) Anopheles nunestovari s.l.

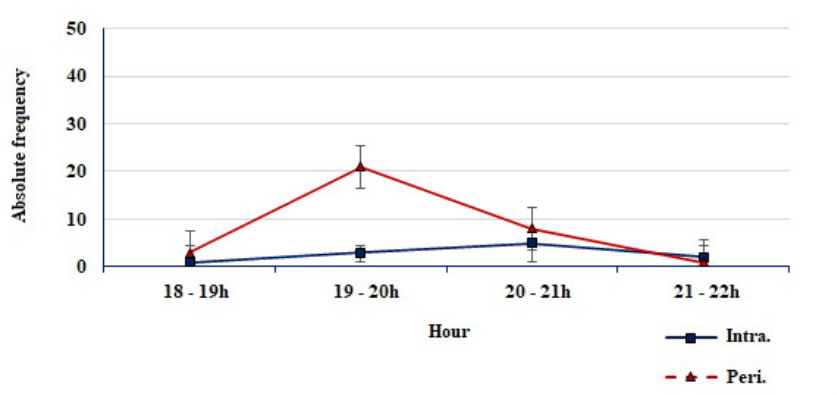

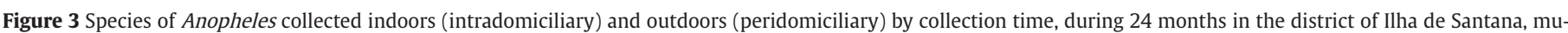

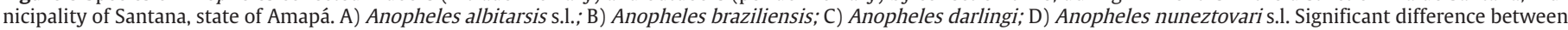

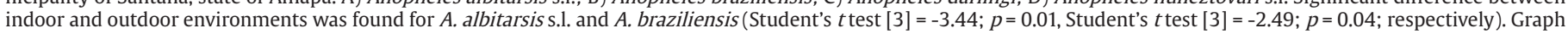
with standard deviation bars. 
seven (1.39\%) were captured near dwellings. Two peaks were observed for this species throughout the collection period, February/2017 and February/2018, with 239 (47.61\%) and 231 (46.01\%) specimens collected, respectively (Fig. 4). The second most abundant species was $A$. albitarsis s.l., with 176 (19.89\%) and the highest abundance was observed in February/2017 with 82 (46.59\%) individuals (Fig. 4). Anopheles darlingi was the third most frequent species with 110 (12.43\%) individuals collected and showed a peak in August/2018, with 60 (55.55\%) specimens captured. Of these, 32 (53.33\%) were captured near dwellings and 28 (46.67\%) in the environment containing animals. For this species, a simultaneous variation was observed between anthropophilic and zoophilic indexes throughout the collection period (Fig. 4). Anopheles braziliensis was the fourth the most abundant species, with 66 (7.46\%) specimens and showed a peak of anthropophilic behavior in May/2018, represented by 17 individuals, and a peak of zoophilic behavior in November/2018, with 41 specimens collected (Fig. 4). No significant differences in abundance between anthropophilic and zoophilic behaviors were found for $A$. albitarsis s.l., A. braziliensis, A. darlingi, and A. nuneztovari s.l.

Of the 885 mosquitoes collected, 119 (13.45\%) individuals displayed anthropophilic behavior and 766 (86.55\%) specimens showed zoophilic behavior. In environment containing animals, with the exception of the first-time interval, a high abundance was observed in all other times. The species with the highest anthropophilic index was $A$. darlingi $\left(\mathrm{I}_{\mathrm{A}}=0.39\right)$, followed by $A$. albitarsis s.l. $\left(\mathrm{I}_{\mathrm{A}}=0.31\right)$, and $A$. braziliensis $\left(\mathrm{I}_{\mathrm{A}}=0.19\right)$, whereas $A$. nuneztovari s.l. ( $\mathrm{Iz}=0.65)$ had the highest zoophilic index (Table 2; Fig. 5). Anopheles intermedius, A. konderi, A. mattogrossesnsis, $A$. peryassui, and $A$. triannulatus had anthropophilic and zoophilic indexes equal or lower that $0.03 \%$. No significant differences between the anthropophilic and zoophilic indices obtained per species were observed (Mann-Whitney U test $=36.5 ; \mathrm{z}=-0.31 ; p=0.75$ ).

When taking into account species distribution per time interval, the number of mosquitoes collected displaying zoophylic behavior was much higher than those captured displaying anthropophilic behavior (Fig. 6). However, only A. albitarsis s.l. showed significant differences between the anthropophilic and zoophilic behaviors per time interval (Student's $t$ test [3] $=-2.67 ; p=0.03$ ).
GLM was also used to determine feeding preferences (anthropophily/ zoophily), time of highest hematophagic activity considering feeding preference, and ratio of general abundance to abundance of the four species collected in greater frequency. Although no significant differences were found between anthropophilic and zoophilic indices (mentioned above), GLM revealed a trend regarding feeding preference, which was as a very significant factor in the abundance of species, indicating preferentially a zoophilic behavior. Another determining factor was collection time, which showed a very significant relationship, confirming the highest zoophilic activity during the second collecting period. Finally, when analyzing the relationship between general abundance and the abundance of the four most frequently collected species, a significantly strong relationship was observed, demonstrating the predominance of the four species collected at the highest densities in the study area (Table 3).

\section{Human biting rate (HBR)}

The highest index of attraction as mosquito/human/hour was observed for $A$. nuneztovari s.l. with 3.00 in the interval $19-20 \mathrm{~h}$. Anopheles albitarsis s.l. had the second highest HBR, ranging from 0.08 to 0.83 at the time intervals: $01-02 \mathrm{~h}, 04-05 \mathrm{~h}$, and $18-19 \mathrm{~h}$. The third species with the highest index was $A$. darlingi with 0.75 , which was collected in almost all time intervals, except in the interval of $20-21 \mathrm{~h}$ (Fig. 7). The remaining species showed HBR ranging from 0.00 to 0.33 .

The analysis of HBR for 12-h collections revealed a significant difference between $A$. darlingiand the species $A$. intermedius, A. konderi, A. mattogrossensis, A. peryassui, and A. triannulatus (Kruskal-Wallis test [8] = 33.02; $p$ < 0.05). Significant differences in HBR were found between the time intervals: $18-00 \mathrm{~h}, 19-23 \mathrm{~h}, 19-00 \mathrm{~h}, 19-01 \mathrm{~h}, 19-02 \mathrm{~h}$, $19-03 \mathrm{~h}, 19-04 \mathrm{~h}$, and $19-05 \mathrm{~h}$ (Kruskal-Wallis test [11] = 15.16; $p<0.05$ ).

\section{Hourly biting activity}

Considering all species captured during 12-h collections, a bimodal peak between the time intervals of $21-22 \mathrm{~h}$ and $02-03 \mathrm{~h}$ was observed for A. mattogrossensis, while A. konderi was collected only in the

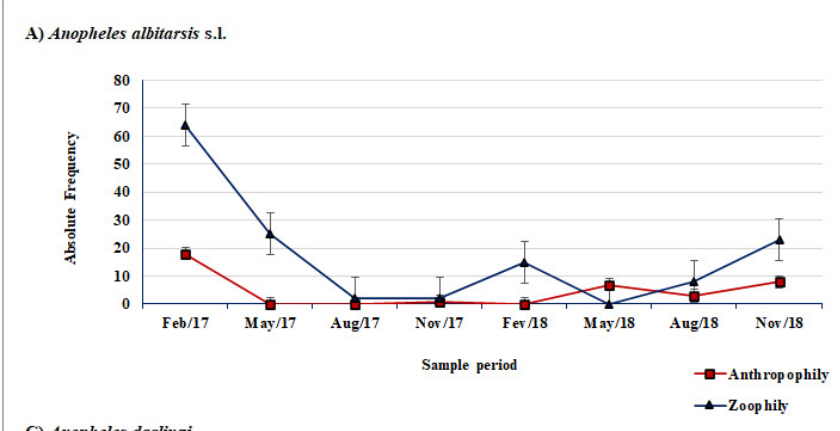

B) Anopheles braziliensis

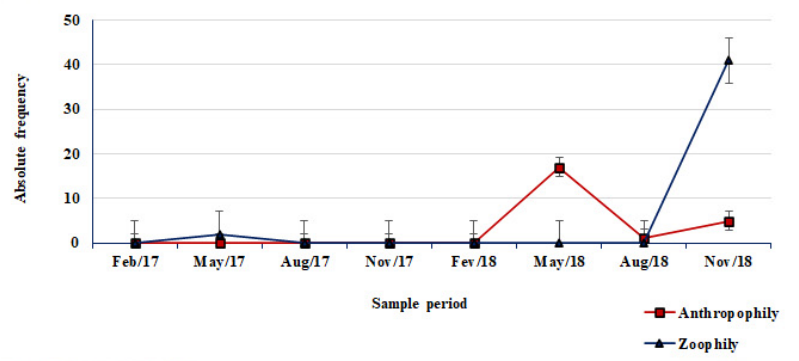

D) Anopheles nuneztovari s.l.

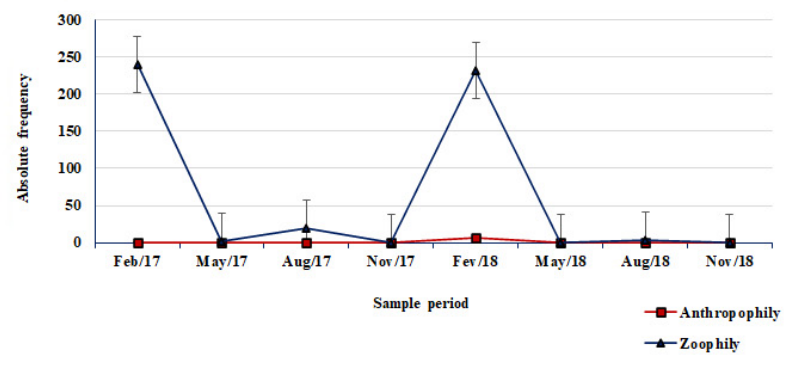

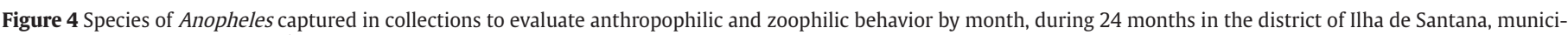

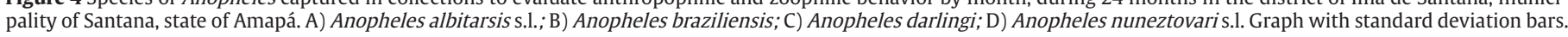




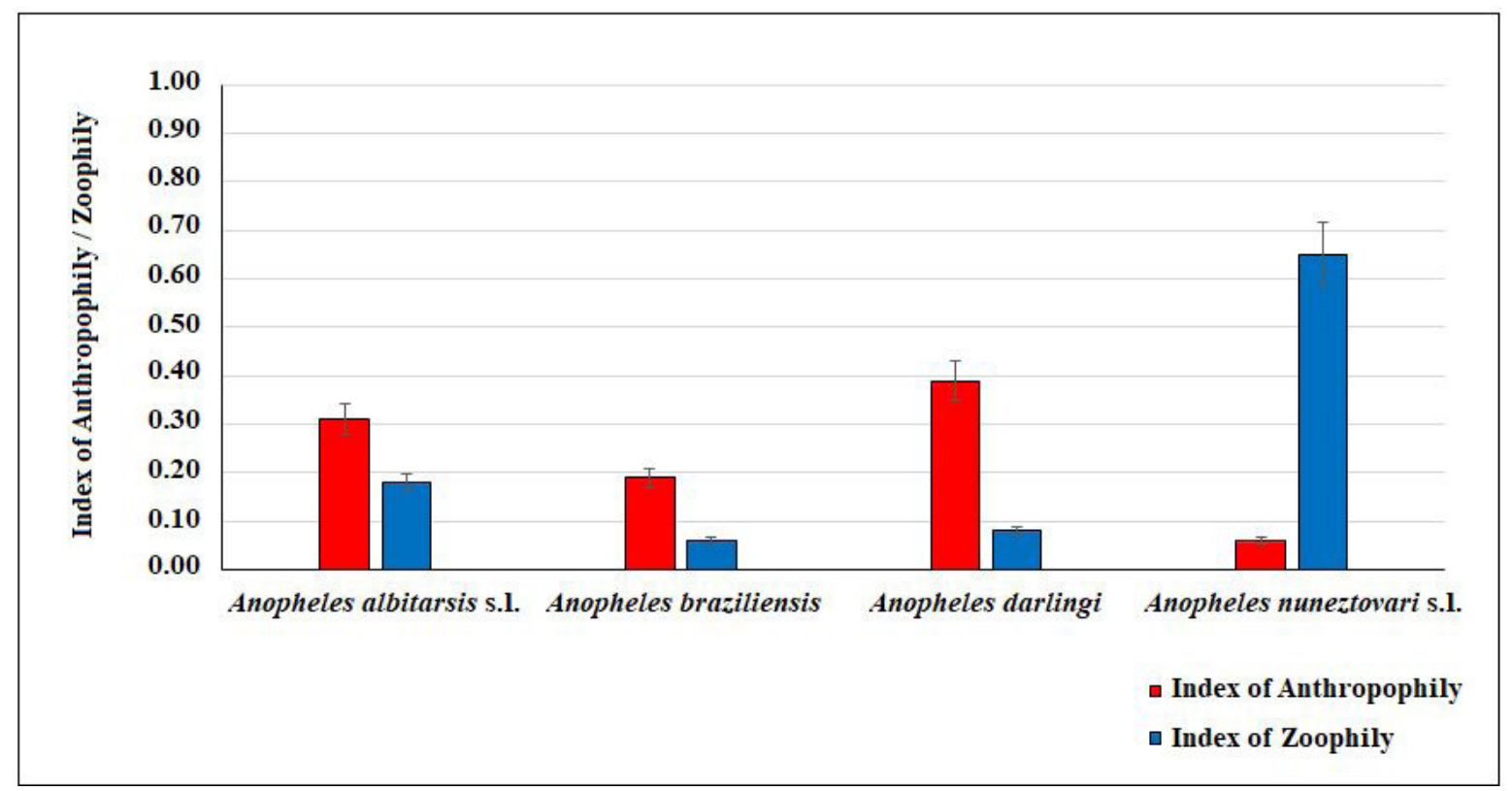

Figure 5 Species of Anopheles captured in collections to evaluate anthropophilic and zoophilic behavior during 24 months in the district of Ilha de Santana, municipality of Santana, state of Amapá. Graph with standard deviation bars.

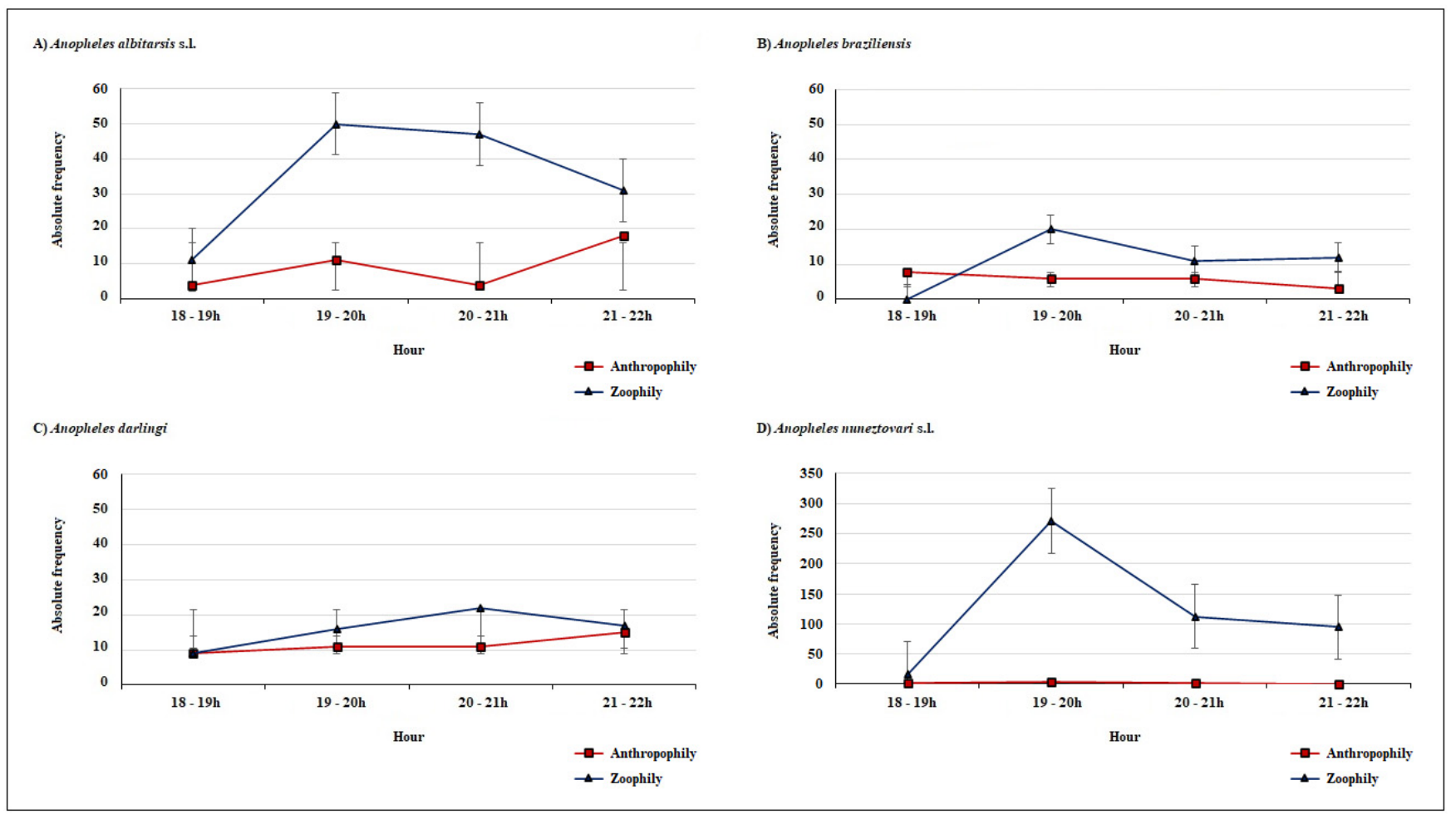

Figure 6 Absolute frequency by time of the main species of Anopheles captured in collections to evaluate anthropophilic and zoophilic behavior in the district of Ilha de Santana, municipality of Santana, state of Amapá; A) Anopheles albitarsis s.l.; B) Anopheles braziliensis; C) Anopheles darlingi; D) Anopheles nuneztovari s.l. Significant difference between the number of anthropophilic and zoophilic individuals was observed only for $A$. albitarsis s.l. (Student's $t$ test [3] $=-2.67 ; p=0.03$ ). Graph with standard deviation bars.

first time interval, consequently showed a unimodal peak. It should be pointed out because these species were captured in low densities. Anopheles braziliensis and $A$. triannulatus had multimodal peaks, although the latter was also found in low densities.

Two well-defined peaks of feeding activity (18 - 19h and $21-22 \mathrm{~h}$ ) were observed for $A$. darlingi, which was not collected in only one time interval $(20-21 \mathrm{~h})$. On the other hand, a unimodal pattern with a peak early in the evening $(19-20 \mathrm{~h})$ was found for A. albitarsis s.l., which was absent in the $22-23 \mathrm{~h} ; 23-00 \mathrm{~h} ; 00-01 \mathrm{~h} ; 03-04 \mathrm{~h} ; 05-06 \mathrm{~h}$ time intervals.

Regarding the hourly biting activity of the main captured species, a significant difference was found between $A$. darlingiand the species A. intermedius, A. konderi, A. mattogrossensis, A. peryassui and A. triannulatus; between $A$. albitarsis s.l. and $A$. konderi; and between 


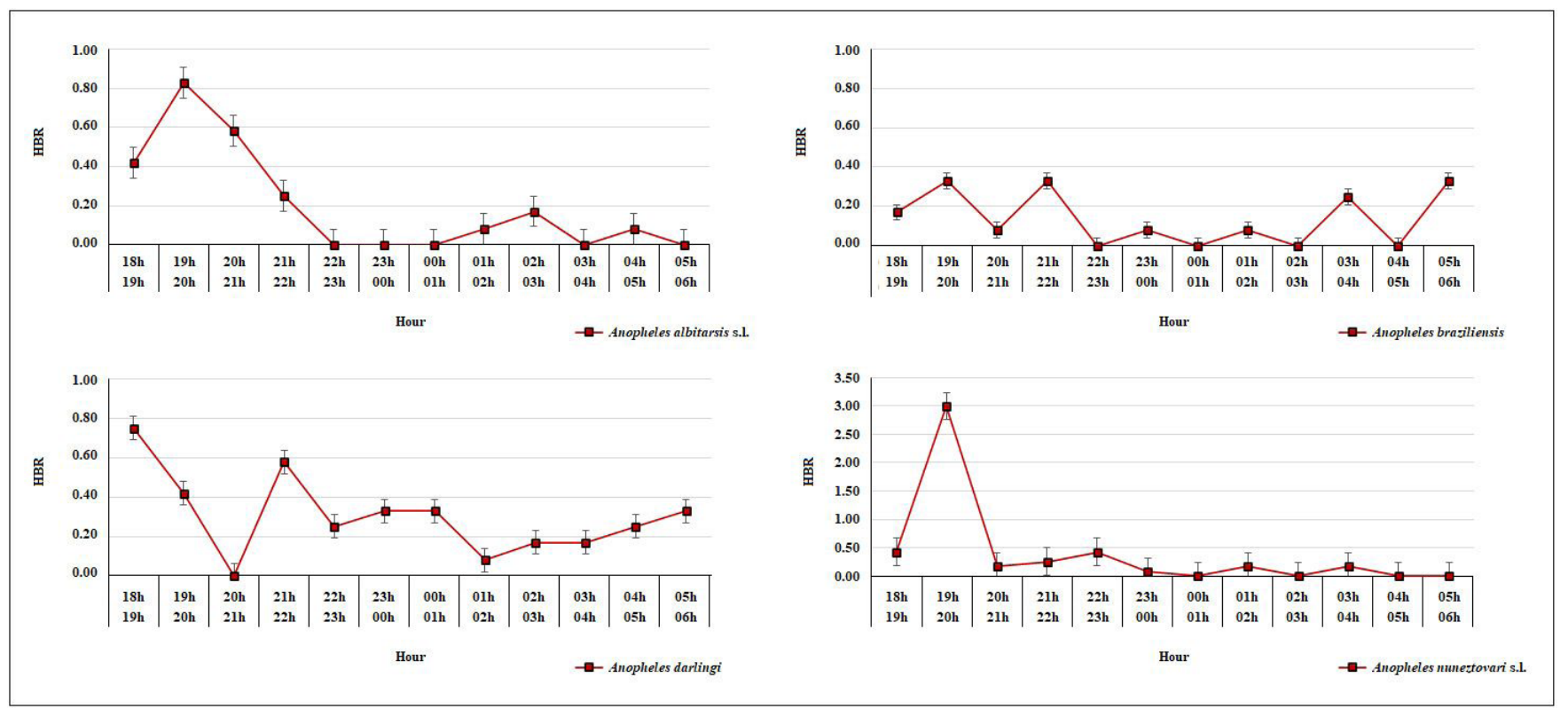

Figure 7 Human biting rate (HBR) of the most abundant species captured in the 12-hour collections in the district of Ilha de Santana, municipality of Santana, state of Amapá. Graph with standard deviation bars.

A. mattogrossensis and $A$. peryassui (Kruskal-Wallis test [11] = 18.79; $p<0.05)$. Activity was clearly higher during the 19 and $20 \mathrm{~h}$ time interval, with a significant difference in biting activity between 18 and $00 \mathrm{~h}$, 19 and 23h, 19 and 00h, 19 and 01h, 19 and 02h, 19 and 03h, 19 and 04h, and 19 and 05h (Kruskal-Wallis test $[8]=40.92 ; p<0.05$ ).

\section{Parity rate}

Based on four-hour collections, the parity rate of $A$. darlingi ranged from 21.42 to 31.58 , with the highest number of parous females (31.58) found in the third time interval $(20-21 \mathrm{~h})$. The parity rates for $A$. albitarsis s.l. (42.86) and $A$. braziliensis (50.00) were highest in the first time interval ( $18-19 \mathrm{~h}$ ). All specimens of $A$. konderi and $A$. mattogrossensis captured were nulliparous. Parous females of $A$. darlingi, $A$. albitarsis s.l., A. braziliensis, and $A$. intermedius were found at all time intervals.

No significant differences in parity rates were found among collection time intervals. However, a significant difference in parity rates was found between $A$. darlingiand $A$. intermedius and between $A$. nuneztovari s.l. and $A$. intermedius (Kruskal-Wallis test [6] $=9.65 ; p<0.05$ ).

In 12-h collections, all $A$. darlingi females captured at the $01-02 \mathrm{~h}$ time interval were parous (100.00), with the parity rate ranging from 25.00 to 100.00 . Another species with one of the highest parity rates was A. albitarsis s.l., varying between 30.00 and 100.00 , with all parous females at the $04-05 \mathrm{~h}$ time interval. Analyzing parity rates by time, a significant difference was found between the intervals 18 and 00h, 19 and 20h, 19 and $22 \mathrm{~h}, 19$ and $00 \mathrm{~h}, 19$ and $02 \mathrm{~h}$ and 19 and $03 \mathrm{~h}$ (Kruskal-Wallis test [11] = 11.27; $p<0.05$ ). When analyzing parity rates by species, a significant difference was observed between $A$. albitarsiss.l. and $A$. mattogrossensis, A. albitarsis s.l. and $A$. konderi, $A$. darlingi and $A$. intermedius, $A$. darlingi and $A$. mattogrossensis, A. darlingi and $A$. konderi, and $A$. darlingi and A. triannulatus (Kruskal-Wallis test [5] $=16.08 ; p<0.05$ ).

In July and September 2017 there was a rise in the number of malaria cases accompanying the increase in anopheline density. For $A$. darlingi, the increase in parity rate was simultaneous with the increase in density of this species, with an overlap in variables. Also, when analyzing the increase in density and the increase in the number of malaria cases, a synchrony during the two malaria peaks also occurred (September/2017 and November/2018)(Fig. 8). The increase in density of $A$. albitarsis s.l. was followed by an increase in the number of cases malaria, with peaks in parity rate along with density (Fig. 8). The same was observed for $A$. braziliensis regarding the increase in density with the number of malaria cases (Fig. 8). For $A$. nuneztovari s.l., a simultaneous variation between density and parity was observed; however, when analyzing density and number of malaria cases, the increase in the number of individuals of this species clearly occurred only after the increase in the number of malaria cases (Fig. 8). The density and parity rate of $A$. albitarsis s.l., A. braziliensis, $A$. darlingi and $A$. nuneztovari s.l. showed a strong, positive and significant correlation. However, no correlation was found between density and number of malaria cases or between parity rate and the number of malaria cases. Despite the already mentioned synchronism observed for $A$. darlingi between density and number of malaria cases.

Minimum infection Rate (MIR) and Entomological inoculation rate (EIR)

In this study, 438 pools were analyzed for Plasmodium species using the PCR technique, distributed as follow: 121 for $A$. darlingi, 95 for $A$. albitarsis s.l., 54 for $A$. braziliensis, 163 for $A$. nuneztovari s.l. and five for Anopheles species. Of these, only one pool was positive for $P$. vivax, which contained one specimen of $A$. darlingi. This specimen was captured during 12-h collections, between 18 and 19 hours and in May/2018, when only ten mosquitoes were collected, of which five were $A$. albitarsis s.l. and five were $A$. darlingi. However, the specimens of $A$. darlingi were captured at different times. The minimum infection rate was $0.83 \%$ for $P$. vivaX, while the monthly EIR was 0.11 infectious bites/human/month and the annual EIR was 1.27 infectious bites/ human/year.

\section{Discussion}

In this study, a total of nine species was captured and the findings revealed that, of the four most abundant species, two (A. darlingi and $A$. albitarsis s.l.) have been appointed as the most important malaria vectors in the state of Amapá (Póvoa et al., 2001; Galardo et al., 2007; Barbosa et al., 2016). 


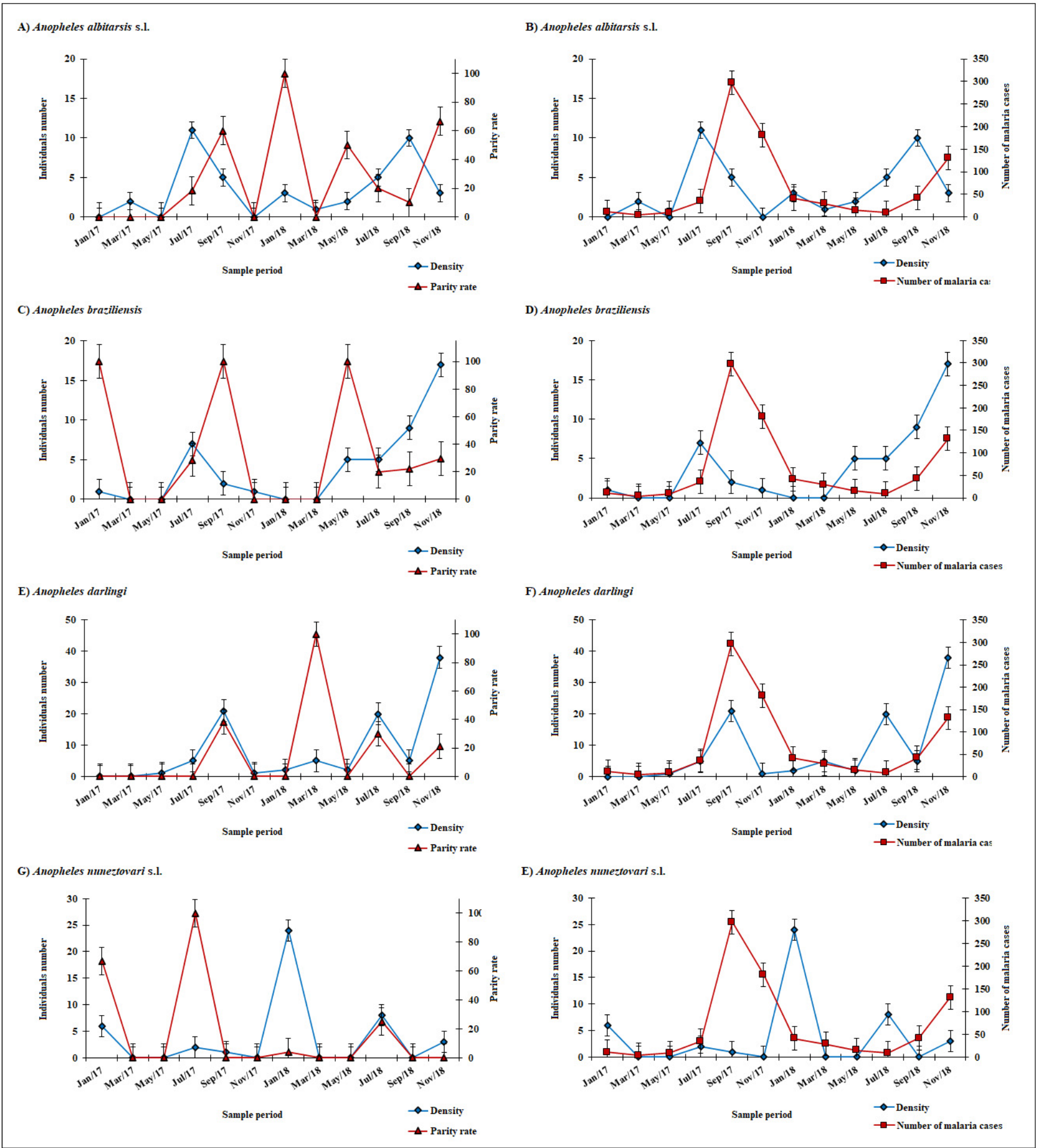

Figure 8 Density of Anopheles species, parity rate, and number of malaria cases by month, during 24 months in the district of Ilha de Santana, municipality of Santana, state of Amapá. A and B) Anopheles albitarsis s.l.; C and D) Anopheles braziliensis; E and F) Anopheles darlingi; G and H) Anopheles nuneztovari s.l. The Spearman correlation between density and parity rate was significant for A. albitarsis s.l. ( $\mathrm{rs}=0.61 ; p=0.03)$, A. braziliensis ( $\mathrm{rs}=0.80 ; p=0.01)$, A. darlingi ( $\mathrm{rs}=0.72 ; p=0.01)$ and $A$. nuneztovari s.l. ( $\mathrm{rs}=0.74$; $p=0.01)$. Graph with standard deviation bars.

The collected species were recorded in all sampling methods, revealing their behavioral plasticity. Although most individuals were collected outdoors, the main species involved in the transmission of malaria in the state of Amapá ( $A$. darlingi and A. albitarsis s.l,) were also collected indoor environment and had the highest anthropophily index $\left(\mathrm{I}_{\mathrm{A}}=0.39 ; 0.31\right.$, respectively). Anopheles nuneztovari s.l. was captured in highest density in this study, but it was the most zoophilic species $\left(\mathrm{I}_{\mathrm{z}}=0.65\right)$. Although $A$. nuneztovari s.l. is considered an important malaria vector in Colombia and Venezuela (Rubio-Palis et al., 1992; Schoeler et al., 2003; Turell et al., 2008; Sinka et al., 2010; NaranjoDíaz et al., 2016), in Brazil this species is considered a secondary vector in some regions, in spite to be found frequently infected with Plasmodium 
species (Santos et al., 2005; Galardo et al., 2007; Rezende et al., 2009). However, some studies carried out in the state of Amapá indicate that $A$. nuneztovaris.l. may contribute to malaria transmission, especially when in high densities (Galardo et al., 2007; Barbosa et al., 2016). In fact, in the Brazilian Amazon this species may consist of two or more species, as was demonstrated by Scarpassa et al. (1996, 2000).

The tools for the control of malaria vectors recommended by the World Health Organization (WHO) are long lasting insecticide treated nets (LLINs) and indoor residual spraying (IRS). However, these methodologies mainly target endophilic anophelines (Prussing et al., 2019). In this study, these control measures can become ineffective against the malaria vectors in the district of Ilha de Santana, due behavior to be predominantly outdoors. An example of unsuccessful IRS was reported in Peru, where Prussing et al. (2018) did not observe a consistent effect of spraying on the abundance of $A$. darlingi. In this case, this method was insufficient to eliminate malaria, and additional strategies were needed (Williams et al., 2018; Prussing et al., 2019).

The GML revealed a significant effect of the variable environment (indoors and outdoors) on abundance of Anopheles species. Anopheles albitarsis s.l. had the second highest index of attraction as mosquito/ human/hour. Since the first studies carried out in the state of Amapá by Deane et al. (1948), A. albitarsis s.l. has been considered a possible secondary vector of malaria, and its epidemiological importance has been supported by Póvoa et al. (2001), Conn et al. (2002), Galardo et al. (2007) and Barbosa et al. (2016), either as primary vector at times or helping the maintenance of the disease in areas of transmission. In this study, A. albitarsis s.l. was found at lower densities throughout the sampling period, and may be helping the maintenance of malaria in the region and playing a role as a secondary vector of the disease.

The greater abundance of anopheline vectors collected outdoor environment allows the assessment of the level of risk of malaria transmission, given the common habit of residents be outside their residences at dusk, when anopheline activity was highest. In this study, A. darlingi exhibited anthropophilic and crepuscular behaviors (dawn and dusk). When analyzing the entire sampling period, however, zoophilic behavior was also observed for this species during the collections carried out in environments with animals, indicating its hematophagic plasticity. When analyzing anthropophilic and zoophilic behaviors by time interval, the anthropophily index was highest in the two species, A. darlingiand $A$. albitarsis s.l., demonstrating their bloodfeeding preferences and epidemiological importance (Barbosa et al., 2016). Also, in 12-hour collections, the number of parous females of $A$. darlingi and $A$. albitarsis s.l. was highest in the first time intervals, confirming that these hours are when the risk for malaria transmission is highest. However, parity rate for both species peaked in the last hours of the night.

Similar results to those observed in the present study were also reported in the state of Maranhão for $A$. albitarsis s.l., A. darlingi, and A. nuneztovaris.l., regarding HBR and with peaks occurring in the first time intervals (Barros et al., 2020). A second peak in the third time interval (21 - 22 hours) was observed for A. darlingi. In the present study, this species had the third highest HBR and was found in almost all collection times, indicating its activity throughout the night (time plasticity). Anopheles albitarsis s.l. and A. braziliensis were captured predominantly in outdoor environment, however, they displayed anthropophilic behavior $\left(\mathrm{I}_{\mathrm{A}}=0.31 ; 0.19\right.$, respectively). These species were less anthropophilic than $A$. darlingi $\left(\mathrm{I}_{\mathrm{A}}=0.39\right)$. Anopheles albitarsis s.l. has been implicated as local vector of malaria in the states of Amapá (Conn et al., 2002; Galardo et al., 2007; Barbosa et al., 2016) and Roraima (Silva-Vasconcelos et al., 2002). Considering the findings obtained with A. braziliensis, further studies are needed to clarify its role in malaria transmission in this area and in other areas of Amapá.
Anopheles intermedius, A. konderi, A. mattogrossensis, A. peryassui, and $A$. triannulatus were found in low densities in all sampling methods, with significant differences in HBR rates compared with $A$. darlingi, supporting that these species are not epidemiologically important in malaria transmission in the studied area. However, some studies have reported A. triannulatus naturally infected with Plasmodium species in Venezuela and Colombia (Moreno et al., 2009; Rosero et al., 2013), and in some states of the Brazilian Amazon (Galardo et al., 2007; Moreno et al., 2013). Despite the wild and zoophilic behavior of these species, $A$. triannulatus can play a role as secondary vector when in high densities, behaving as an opportunistic species, depending on host availability and abundance (Galardo et al., 2007; Rosero et al., 2013). These variations in behavior may be associated with the existence of a cryptic species complex, consisting of at least three species (Anopheles triannulatuss.s. Neiva and Pinto, 1922; Anopheles halophylus Silva-doNascimento and Lourenço-de-Oliveira, 2002; and Anopheles triannulatus C Silva-do-Nascimento et al., 2006).

Although $A$. nuneztovari s.l. was found indoors, this species was abundant in environments with animals, where it displayed a zoophilic behavior throughout the sample period, confirming its feeding preference in the study area. Members of the Nuneztovari complex are widely distributed from eastern Panama to northern South America and throughout the Amazon basin, in Bolivia, Brazil, Colombia, Ecuador, Guyana, Peru, and Venezuela (Sinka et al., 2010). This complex comprises four species: Anopheles nuneztovari s.s. Gabaldón, 1940; Anopheles goeldii Rozeboom and Gabaldón, 1941; Anopheles dunhami Causey, 1945; and Anopheles nuneztovari cytotype A (Sant'Ana et al., 2015; Santos et al., 2019), with variations in behavior, vector capacity, and involvement in malaria transmission. In the Brazilian Amazon, A. nuneztovari s.l. may be a local vector, displaying mainly exophilic and zoophilic behaviors (Galardo et al., 2007; Barbosa et al., 2016). However, in Colombia and Venezuela, A. nuneztovaris.s. is endophilic, exophilic and anthropophilic (Moreno et al., 2007; Gutiérrez et al., 2009; Naranjo-Díaz et al., 2013; Naranjo-Díaz et al., 2016).

Despite a higher abundance of zoophilic individuals collected in the months of February, May and August 2017, A. darlingi was collected displaying both anthropophilic and zoophilic behaviors in nearly equal numbers during the entire sampling period, but with the index of anthropophily slightly higher. Regarding biting activity, although $A$. darlingi was active in almost throughout night, a bimodal pattern was observed early in the evening, between 18 and 19 hours and between 21 and 22 hours.

Anopheles darlingi does not have well-defined standards of biting activity (Gil et al., 2015; Lainhart et al., 2015; Moreno et al., 2015; Tadei et al., 2017; Saavedra et al., 2019), likely due to environmental variables and very high levels of intra-population genetic variation. Anopheles albitarsis s.l. was more active early in the evening, with a lower peak at 02 hours. This unimodal pattern was also reported in other location from Amapá (Voorham, 2002) and in the state of Roraima (Póvoa et al., 2006), Brazil, and in western Venezuela (Rubio-Palis and Curtis, 1992).

During four-hour collections, parity rates of $A$. darlingiand $A$. albitarsis s.l. were high, with occurrence of parous females at all time intervals, indicating a greater risk of malaria transmission. The increase in the number of malaria cases coincided with the increase in A. darlingi density, as well as with in parity. These results, combined with a positive test for $P$. vivax, clearly indicate the involvement of this species in the malaria transmission in the district of Ilha de Santana, and confirm its role as the main malaria vector in the Amazon region. Our findings about the behavior of $A$. darlingi in the state of Amapá is in agreement with the reported by Deane et al. (1948), Lourenço-de-Oliveira et al. 
(1989), Klein and Lima (1990), Osorio Quintero et al. (1996), Tadei et al. (1998), Moutinho et al. (2011) and Barbosa et al. (2016).

Anopheles darlingi was positive with $P$. vivax in the first time interval (18 - 19h), confirming the time of greatest risk of malaria infection by residents. Despite the single positive pool, the infection rate was similar to those found in Cahuide and Santa Emilia, in Peru (Prussing et al., 2018). In the Americas, the highest prevalence of malaria is caused by P. vivax, representing $75 \%$ of cases of infections, a milder and rarely lethal form (WHO, 2019). However, this type of malaria is responsible for most cases of relapse, as it develops latent forms in the liver cells (hypnozoites), and can remain inactive for years (White et al., 2014).

In this study, although the rate of infection with Plasmodium species was low, the district of Ilha de Santana is an area susceptible to malaria outbreaks, because consecutive epidemic cycles can occur even with low parasitemia (Klein et al., 1991; Alves et al., 2005). The main species responsible for the transmission of malaria were identified in the study area in high densities compared to other species. This is an important public health issue, since the migratory flow of people to the district of Ilha de Santana from other malarial areas of the Amazon may promote the local spread of the malaria parasite, triggering the disease (Barbosa et al., 2014).

Anopheles darlingi is the main vector of malaria in the Brazilian Amazon and one of the most anthropophilic anophelines, and its behavior is very heterogeneous. The district of Ilha de Santana has favorable characteristics for the development of this species, with areas of preserved vegetation (forest area, savanna, mangrove) and streams. In addition, human activity has increased in this district, as a result of deforestation for the development of agricultural activities and the construction of fish tanks, as well as intense migratory flow. These factors can favor the increase of the density of $A$. darlingi and contribute to the continuous transmission of malaria.

When analyzing the correlation between density and parity of A. darlingi, A. albitarsis s.l., A. braziliensis, and A. nuneztovari s.l., a strong correlation was observed, indicating that the higher the abundance is associated with the higher the number of parous females. In the months when the density of these species increases, Plasmodium circulation increases, as well as the chances of outbreaks.

In Venezuela, in riverine villages located in Bolívar, of 2,707 mosquitoes analyzed by ELISA, only two pools of $A$. darlingi were positive out of a total of 1,118 specimens analyzed (Rubio-Palis et al., 2013). In a study carried out in Colombia, the sporozoite rate obtained was $0.13 \%$, lower than our findings, and only one positive individual of $A$. darlingi was found, also for $P$. vivax (Jiménez et al., 2014). Overall, infection rates in anophelines are very low, varying between 0.1 and 3.7\% (Tucker Lima et al., 2017), supporting our findings.

In the present study, some factors may have influenced the low density of anophelines throughout the collections, such as the habit of some residents to light fires in front of homes to repel mosquitoes and the use of pesticides in plantations, a common practice in the rural area of Ilha de Santana. Indoor residual spraying in September/2017 during three consecutive days and in March and May/2018 by the Health and Surveillance Coordination, likely contributed to the low abundance of anophelines species in the studied area. Another factor that might have influenced this reduction was the intense fires, a very common practice between September and November, which are the months warmest and driest of the year in region.

\section{Conclusion}

Anopheles darlingi was the most abundant species in four-hour collections, the most frequent anopheline indoors, the most anthropophilic, and the only species positive for $P$. vivax, confirming its epidemiological importance and its involvement in the transmission of malaria in the district of Ilha de Santana. Anopheles darlingialso had the highest hourly biting activity and HBR in the first hours with a high parity rate, confirming the early evening as period with the highest activity of this species and coinciding with time when residents are most exposed. Anopheles albitarsis s.l. was also the second species more anthropophilic, consequently it may play an important role in the transmission of malaria in this district, harmoniously coexisting with $A$. darlingi. The behavior of $A$. braziliensis was a similar to that of $A$. albitarsis s.l., being found predominantly outdoors with some anthropophilic tendencies. An increase in density was observed for this species, with peaks that preceded a rise in malaria cases. Therefore, the role of $A$. braziliensis as malaria vector in the study area needs to be investigated. Although $A$. nuneztovari s.l. had highest density in this study, it was collected predominantly in outdoor environment and displayed a zoophilic behavior, with peaks after the increase in the number of malaria cases. Taken together, these findings suggest that this species is not involved in malaria transmission in the district of Ilha de Santana.

Finally, although we recognized the importance of current control methods applied in the district of Ilha de Santana, we recommend complementary control strategies tailored to local conditions, given the inherent characteristics of $A$. darlingi, its high adaptive capacity in anthropic environments as well as its behavioral plasticity (predominantly outdoors) and heterogeneity, in order to meet the goals established by WHO in the control and eradication of malaria.

\section{Acknowledgments}

To the field team of JCC Mendes, AM Rodrigues, JRN Costa, MO Brito Filho, FB Medes, for support in collecting mosquito samples.

\section{Funding}

This research was funded by INPA/MCTI - Biology and ecology of insects of the Amazon Project (Grant Number: PRJ12.311), by PRO-EQUIPAMENTOCAPES, Brazil, and supported by the Federal University of Amapá, Brazil.

\section{Conflicts of interest}

The authors declare no conflicts of interest.

\section{Compliance with ethical standards}

This study was approved by the Research Ethics Committee of the Federal University of Amapá, registered under \#78912617.9.0000.0003. The collection and transport of the target specimens was authorized by Brazilian Environmental Institute (IBAMA) through the Biodiversity Information and Authorization System (SISBIO) under \#52442-1.

\section{Author contribution statement}

VM and LMCB Conceptualization and Designed the experiment. LMCB Collected and identified the specimens. LMCB Generated the data. LMCB Processed the statistical analyzes. LMCB and VMS Wrote the manuscript. VMS and LMCB: Revised and edited the manuscript. All authors reviewed and approved the manuscript.

\section{References}

Alves, F. P., Gil, L. H. S., Marrelli, M. T., Ribolla, P. E. M., Camargo, E. P., Silva, L. H. P., 2005. Asymptomatic carriers of Plasmodium spp. as infection 
source for malaria vector mosquitoes in the Brazilian Amazon. J. Med. Entomol. 42 (5), 777-779. http://dx.doi.org/10.1603/00222585(2005)042[0777:ACOPSA]2.0.CO;2.

Ayres, M., Ayres, M. J. R., Ayres, D. L., Santos, A. S., 2007. BioEstat 5.0: aplicações estatísticas nas áreas das ciências biológicas e médicas. Publicações Avulsas do Mamirauá, Belém.

Barbosa, L. M. C., Souto, R. N. P., Ferreira, R. M. A., Scarpassa, V. M., 2014. Composition, abundance and aspects of temporal variation in the distribution of Anopheles species in an area of Eastern Amazonia. Rev. Soc. Bras. Med. Trop. 47 (3), 313-320. http://dx.doi. org/10.1590/0037-8682-0239-2013.

Barbosa, L. M. C., Souto, R. N. P., Ferreira, R. M. A., Scarpassa, V. M., 2016. Behavioral patterns, parity rate and natural infection analysis in anopheline species involved in the transmission of malaria in the northeastern Brazilian Amazon region. Acta Trop. 164, 216-225. http://dx.doi.org/10.1016/j.actatropica.2016.09.018.

Barros, V. L. L., Costa, F. M., Silva, A. R., Gonçalvez, E. G. R., Bezerra, D. S., Lorosa, E. S., Tadei, W. P., 2020. Study of behavioral patterns and infection analyses in anopheline species involved in the transmission of malaria in Buriticupu and São José de Ribamar municipality, Maranhão State, Brazil. EntomoBrasilis 13, e0820. http://dx.doi. org/10.12741/ebrasilis.v13.e0820.

Bergo, E. S., Souto, R. N. P., Galardo, A. K. R., Nagaki, S. S., Calado, D. C., Sallum, M. A. M., 2007. Systematic notes on Anopheles Meigen (Diptera: Culicidae) species in the state of Amapá, Brazil. Mem. Inst. Oswaldo Cruz 102 (3), 373-376. http://dx.doi.org/10.1590/ S0074-02762007005000053.

Chaves, L. S. M., Conn, J. E., López, R. V. M., Sallum, M. A. M., 2018. Abundance of impacted forest patches less than $5 \mathrm{~km} 2$ is a key driver of the incidence of malaria in Amazonian Brazil. Sci. Rep. 8 (1), 1-11. http://dx.doi.org/10.1038/s41598-018-25344-5.

Conn, J. E., Wilkerson, R. C., Segura, M. N. O., Souza, R. T. L., Schlichtinh, C. D., Wirtz, R. A., Póvoa, M. M., 2002. Emergence of a new Neotropical malaria vector facilitated by human migration and changes in land use. Am. J. Trop. Med. Hyg. 66 (1), 18-22. http://dx.doi.org/10.4269/ ajtmh.2002.66.18.

Consoli, R. A. G. B., Lourenço-de-Oliveira, R., 1994. Principais mosquitos de importância sanitária no Brasil. Fiocruz, Rio de Janeiro.

Deane, L. M., Causey, O. R., Deane, M. P., 1948. Notas sobre a distribuição e a biologia dos anofelinos das regiões nordestina e amazônica do Brasil. Rev. Serv. Esp. Saude Publica 1, 827-963.

Deane, L. M., Deane, M. P., Ferreira Neto, J. A., Almeida, F. B., 1971. On the transmission of simian malaria in Brazil. Rev. Inst. Med. Trop. 13, 311-319.

Detinova, T. S. 1962. Age Grouping Methods in Diptera of Medical Importance with Special Reference to Some Vectors of Malaria. World Health Organization, Geneva. (Monograph Series).

Faran, M. E., Linthicum, K. J., 1981. A handbook of the Amazonian species of Anopheles (Nyssorhynchus) (Diptera: Culicidae). Mosq. Syst. 13, 1-91.

Forattini, O. P. 1962. Entomologia médica. Universidade de São Paulo, São Paulo.

Forattini, O. P. 2002. Culicidologia médica. Universidade de São Paulo, São Paulo.

Forattini, O. P., Kakitani, I., Santos, R. L. C., Ueno, H. M., Kobayashi, K. M., 1999. Role of Anopheles (Kerteszia) bellator as malaria vector in South-Eastern Brazil. Mem. Inst. Oswaldo Cruz 94 (6), 715-723. http://dx.doi.org/10.1590/S0074-02761999000600001.

Galardo, A. K. R., Arruda, M., D’Almeida Couto, A. A. R., Wirtz, R., Lounibos, L. P., Zimmerman, R. H., 2007. Malaria vector incrimination in three rural riverine villages in the Brazilian Amazon. Am. J. Trop. Med. Hyg. 76 (3), 461-469. http://dx.doi.org/10.4269/ajtmh.2007.76.461.
Galardo, A. K. R., Póvoa, M. M., Sucupira, I. M. C., Galardo, K. D., Santos, R. C., 2015. Anopheles darlingi and Anopheles marajoara (Diptera: Culicidae) susceptibility to pyrethroids in an endemic area of the Brazilian Amazon. Rev. Soc. Bras. Med. Trop. 48 (6), 765-769. http:// dx.doi.org/10.1590/0037-8682-0082-2015.

Gil, L. H. S., Rodrigues, M. D. S., Lima, A. A., Katsuragawa, T. H., 2015. Seasonal distribution of malaria vectors (Diptera: Culicidae) in rural localities of Porto Velho, Rondônia, Brazilian Amazon. Rev. Inst. Med. Trop. São Paulo 57 (3), 263-267. http://dx.doi.org/10.1590/ S0036-46652015000300014.

Glunt, K. D., Abilio, A. P., Bassat, Q., Bulo, H., Gilbert, A. E., Huijben, S., Manaca, M. N., Macete, E., Alonso, P., Paaijmans, K., 2015. Longlasting insecticidal nets no longer effectively kill the highly resistant Anopheles funestus of southern Mozambique. Malar. J. 14 (1), 298304. http://dx.doi.org/10.1186/s12936-015-0807-z.

Gomes, E. C. S., Albuquerque, C. M. R., Souza, J. R. B., Arruda, M. E., Confalonieri, U. E. C., 2008. Structure of Anopheles(Diptera: Culicidae) population in areas with different degrees of human settlement: Cantá - Roraima - Brazil. Acta Amazon. 38 (2), 321-329. http:// dx.doi.org/10.1590/S0044-59672008000200016.

Gouveia de Almeida, A. P., 2011. Os mosquitos (Diptera, Culicidae) e a sua importância médica em Portugal: desafios para o século XXI. Acta Med. Port. 24 (6), 961-974.

Guimarães, J. H. 1997. Systematics Database of Diptera of the Americas South of the United States, Family Culicidae, Sociedade Brasileira de Entomologia, São Paulo.

Gutiérrez, L. A., González, J. J., Gómez, G. F., Castro, M. I., Rosero, D. A., Luckhart, S., Conn, J. E., Correa, M. M., 2009. Species composition and natural infectivity of anthropophilic Anopheles (Diptera: Culicidae) in the States of Córdoba and Antioquia, northwestern Colombia. Mem. Inst. Oswaldo Cruz 104 (8), 1117-1124. http:// dx.doi.org/10.1590/S0074-02762009000800008.

Hiwat, H., Bretas, G., 2011. Ecology of Anopheles darlingi Root with respect to vector importance: a review. Parasit. Vectors 4 (1), 177221. http://dx.doi.org/10.1186/1756-3305-4-177.

Horsfall, W. R., 1943. Some responses of the malaria mosquito to light. Ann. Entomol. Soc. 36 (1), 41-45. http://dx.doi.org/10.1093/aesa/36.1.41.

Instituto Brasileiro de Geografia e Estatística - IBGE, 2013. Áreas dos municípios. Available in: http://web.archive.org/web/20171106155114/ https://www.ibge.gov.br/geociencias-novoportal/organizacao-doterritorio/estrutura-territorial/2225-np-areas-dos-municipios/15761areas-dos-municipios.html?t=destaques\&c=1600600 (accessed 29 September 2019).

Instituto Brasileiro de Geografia e Estatística - IBGE, 2017. Censo demográfico do Amapá. Santana: IBGE. Available in: https://cidades. ibge.gov.br/brasil/ap/santana/panorama (accessed 03 January 2017).

Instituto Brasileiro de Geografia e Estatística - IBGE, 2020. Cidades. Available in: https://cidades.ibge.gov.br/ (accessed 12 May 2020).

Jiménez, I. P., Conn, J. E., Brochero, H., 2014. Preliminary biological studies on larvae and adult Anopheles mosquitoes (Diptera: Culicidae) in Miraflores, a malaria endemic locality in Guaviare department, Amazonian Colombia. J. Med. Entomol. 51 (5), 1002-1009. http:// dx.doi.org/10.1603/ME13146.

Klein, T. A., Lima, J. B., 1990. Seasonal distribution and biting patterns of Anopheles mosquitoes in Costa Marques, Rondônia, Brazil. J. Am. Mosq. Control Assoc. 6 (4), 700-707.

Klein, T. A., Lima, J. B., Tada, M. S., Miller, R., 1991. Comparative susceptibility of anopheline mosquitoes in Rondônia Brazil, to infection by Plasmodium vivax. Am. J. Trop. Med. Hyg. 45 (4), 463470. http://dx.doi.org/10.4269/ajtmh.1991.45.463.

Kuwabara, E. F. 2008. Ecologia de Culicidae (Diptera) e fisiologia de Anopheles (Kerteszia) cruzii Dyar \& Knab, 1908 em área litorânea 
do Estado do Paraná, Brasil. PhD Thesis, Universidade Federal do Paraná, Curitiba.

Lainhart, W., Bickersmith, S. A., Nadler, K. J., Moreno, M., Saavedra, M. P., Chu, V. M., Ribolla, P. E., Vinetz, J. M., Conn, J. E., 2015. Evidence for temporal population replacement and the signature of ecological adaptation in a major Neotropical malaria vector in Amazonian Peru. Malar. J. 14 (1), 375-392. http://dx.doi.org/10.1186/s12936015-0863-4.

Li, X., Huang, J., Zhang, M., Funakoshi, R., Sheetij, D., Spaccapelo, R., Crisanti, A., Nussenzweig, V., Nussenzweig, R. S., Tsuji, M., 2016. Human CD8+ T cells mediate protective immunity induced by a human malaria vaccine in human immune system mice. Vaccine 34 (38), 4501-4506. http://dx.doi.org/10.1016/j.vaccine.2016.08.006.

Lourenço-de-Oliveira, R., Guimarães, A. G., Arlé, M., Silva, T. F., Castro, M. G., Motta, M. A., Deane, L. M., 1989. Anopheline species, some of their habits and relation to malaria in endemic areas of Rondônia state, Amazon region of Brazil. Mem. Inst. Oswaldo Cruz 84 (4), 501-514. http://dx.doi.org/10.1590/S0074-02761989000400008.

Madeira, J. L., Simões, C. C. S., 1972. Estimativas preliminares da população urbana e rural segundo as unidades de Federação, 1960/1980: por uma nova metodologia. Rev. Bras. Estat. 33 (129), 3-11.

Ministério da Saúde - MS, 2019a. Guia para o planejamento das ações de captura de Anofelinos pela Técnica de Atração por Humano Protegido (TAHP) e acompanhamento dos riscos à saúde do profissional capturador. Secretaria de Vigilância em Saúde, Departamento de Vigilância Epidemiológica, Ministério da Saúde, Brasília, 27 pp.

Ministério da Saúde - MS, 2019b. Sistema de Informação de Vigilância Epidemiológica da Malária (SVS/SIVEP). Ministério da Saúde, Brasília. Available in: www.saude.gov.br/sivep_malaria (accessed 12 October 2019).

Ministério da Saúde - MS, 2020a. Biblioteca virtual em saúde. Ministério da Saúde, Brasília, 3 pp.

Ministério da Saúde - MS, 2020b. Sistema de Informação de Vigilância Epidemiológica da Malária (SVS/SIVEP). Ministério da Saúde, Brasília. (Boletim Epidemiológico). Available in: www.saude.gov. br/sivep_malaria (accessed 05 September de 2020).

Moreno, J. E., Rubio-Palis, Y., Páez, E., Pérez, E., Sánchez, V., 2007. Abundance, biting behaviour and parous rate of anopheline mosquito species in relation to malaria incidence in gold-mining areas of southern Venezuela. Med. Vet. Entomol. 21 (4), 339-349. http://dx.doi.org/10.1111/j.1365-2915.2007.00704.x.

Moreno, J. E., Rubio-Palis, Y., Páez, E., Pérez, E., Sánchez, V., Vaccari, E., 2009. Malaria entomological inoculation rates in gold mining áreas of Southern Venezuela. Mem. Inst. Oswaldo Cruz 104 (5), 764-768. http://dx.doi.org/10.1590/S0074-02762009000500017.

Moreno, M., Bickersmith, S., Harlow, W., Hildebrandt, J., McKeon, S. N., Silva-do-Nascimento, T. F., Loaiza, J. R., Ruiz, F., Lourenço-de-Oliveira, R., Sallum, M. A. M., Bergo, E. S., Fritz, G. N., Wilkerson, R. C., Linton, Y. M., Juri, M. J. D., Rangel, Y., Póvoa, M. M., Gutiérrez-Builes, L. A., Correa, M. M., Conn, J. E., 2013. Phylogeography of the neotropical Anopheles triannulatus complex (Diptera: Culicidae) supports deep structure and complex patterns. Parasit. Vectors 6 (1), 47-64. http:// dx.doi.org/10.1186/1756-3305-6-47.

Moreno, M., Saavedra, M. P., Bickersmith, S. A., Lainhart, W., Tong, C., Alava, F., Vinetz, J. M., Conn, J. E., 2015. Implications for changes in Anopheles darlingi biting behaviour in three communities in the peri-Iquitos region of Amazonian Peru. Malar. J. 14 (1), 290-301. http://dx.doi.org/10.1186/s12936-015-0804-2.

Moutinho, P. R., Gil, L. H. S., Cruz, R. B., Ribolla, P. E. M., 2011. Population dynamics, structure and behavior of Anopheles darlingi in a rural settlement in the Amazon rainforest of Acre, Brazil. Malar. J. 10 (1), 174-186. http://dx.doi.org/10.1186/1475-2875-10-174.
Naranjo-Díaz, N., Rosero, D. A., Rua-Uribe, G., Luckhart, S., Correa, M. M., 2013. Abundance, behavior and entomological inoculation rates of anthropophilic anophelines from a primary Colombian malaria endemic area. Parasit. Vectors 6 (1), 61-72. http://dx.doi. org/10.1186/1756-3305-6-61.

Naranjo-Díaz, N., Sallum, M. A. M., Correa, M. M., 2016. Population dynamics of Anopheles nuneztovari in Colombia. Infect. Genet. Evol. 45, 56-65. http://dx.doi.org/10.1016/j.meegid.2016.08.019.

Osorio Quintero, L., Dutary Thatcher, B., Tadei, W. P., 1996. Biologia de anofelinos amazônicos. XXI. Ocorrência de espécies de Anopheles e outros culicideos na área de influência da Hidrelétrica de Balbina, cinco anos após o enchimento do reservatório. Acta Amazon. 26 (4), 281-296. http://dx.doi.org/10.1590/1809-43921996264296.

Pan American Health Organization - PAHO, 2009. Available in: http://new.paho. org/bra/index.php?option=com_content\&task=view\&id=401\&Itemid=259 (accessed 26 August 2019).

Póvoa, M. M., Wirtz, R. A., Lacerda, R. N. L., Miles, M. A., Warhurst, D., 2001. Malaria vectors in the municipality of Serra do Navio, state of Amapá, Amazon region, Brazil. Mem. Inst. Oswaldo Cruz 96 (2), 179-184. http://dx.doi.org/10.1590/S0074-02762001000200008.

Póvoa, M. M., Souza, R. T. L., Lacerda, R. N. L., Santa Rosa, E., Galiza, D., Souza, J. R., Wirtz, R. A., Schlichting, C. D., Conn, J. E., 2006. The importance of Anopheles albitarsis E and An. darlingi in human malaria transmission in Boa Vista, state of Roraima, Brazil. Mem. Inst. Oswaldo Cruz 101 (2), 163-168. http://dx.doi.org/10.1590/ S0074-02762006000200008.

Prussing, C., Moreno, M., Saavedra, M. P., Bickersmith, S. A., Gamboa, D., Alava, F., Schlichting, C. D., Emerson, K. J., Vinetz, J. M., Conn, J. E., 2018. Decreasing proportion of Anopheles darlingibiting outdoors between long-lasting insecticidal net distributions in peri-Iquitos. Amazonian Peru. Malar. J. 17 (1), 86-100. http://dx.doi.org/10.1186/ s12936-018-2234-4.

Prussing, C., Saavedra, M. P., Bickersmith, S. A., Alava, F., Guzmán, M., Manrique, E., Carrasco-Escobar, G., Moreno, M., Gamboa, D., Vinetz, J. M., Conn, J. E., 2019. Malaria vector species in Amazonian Peru co-occur in larval habitats but have distinct larval microbial communities. PLoS Negl. Trop. Dis. 13 (5), e0007412. http://dx.doi. org/10.1371/journal.pntd.0007412.

R Core Team, 2021. R: A Language and Environment for Statistical Computing. R Foundation for Statistical Computing, Vienna. Available in: https://www.R-project.org/ (accessed 26 August 2019).

Ranson, H., Lissenden, N., 2016. Insecticide resistance in African Anopheles mosquitoes: a worsening situation that needs urgent action to maintain malaria control. Trends Parasitol. 32 (3), 187-196. http://dx.doi.org/10.1016/j.pt.2015.11.010.

Rezende, H. R., Soares, R. M., Cerutti Junior, C., Alves, I. C., Natal, D., Urbinatti, P. R., Yamasaki, T., Falqueto, A., Malafronte, R. S., 2009. Entomological characterization and natural infection of anophelines in an area of the Atlantic Forest with autochthonous malaria cases in mountainous region of Espírito Santo State, Brazil. Neotrop. Entomol. 38 (2), 272-280. http://dx.doi.org/10.1590/S1519-566X2009000200017.

Rosero, D. A., Naranjo-Díaz, N., Alvarez, N., Cienfuegos, A. V., Torres, C., Luckhard, S., Correa, M. M., 2013. Colombian Anopheles triannulatus (Diptera: Culicidae) Naturally Infected with Plasmodium spp. Parasitol. 2013, 927453. http://dx.doi.org/10.5402/2013/927453.

Rubio-Palis, Y., Bevilacqua, M., Medina, D. A., Moreno, J. E., Cárdenas, L., Sánchez, V., Estrada, Y., Anaya, W., Martínez, A., 2013. Malaria entomological risk factors in relation to land cover in the Lower Caura River Basin, Venezuela. Mem. Inst. Oswaldo Cruz 108 (2), 220-228. http://dx.doi.org/10.1590/0074-0276108022013015.

Rubio-Palis, Y., Curtis, C. F., 1992. Biting and resting behaviour of anophelines in western Venezuela and implications for control of 
malaria transmission. Med. Vet. Entomol. 6 (4), 325-334. http:// dx.doi.org/10.1111/j.1365-2915.1992.tb00628.x.

Rubio-Palis, Y., Wirtz, R. A., Curtis, C. F., 1992. Malaria entomological inoculation rates in western Venezuela. Acta Trop. 52 (2-3), 167-174. http://dx.doi.org/10.1016/0001-706X(92)90033-T.

Saavedra, M. P., Conn, J. E., Alava, F., Carrasco-Escobar, G., Prussing, C., Bickersmith, S. A., Sangama, J. L., Fernandez-Minope, C., Guzman, M., Tong, C., Valderrama, C., Vinetz, J. M., Gamboa, D., Moreno, M., 2019. Higher risk of malaria transmission outdoors than indoors by Nyssorhynchus darlingi in riverine communities in the Peruvian Amazon. Parasit. Vectors 12 (1), 374-389. http://dx.doi.org/10.1186/ s13071-019-3619-0.

Sambrook, J., Russell, D. W., 2001. Molecular Cloning: A Laboratory Manual. Cold Spring Harbor Laboratory Press, New York.

Sant'Ana, D. C., Bergo, E. S., Sallum, M. A. M., 2015. Anopheles goeldii Rozeboom \& Gabaldón (Diptera, Culicidae): a species of the Nuneztovari Complex of Anopheles Meigen. Rev. Bras. Entomol. 59 (1), 68-76. http://dx.doi.org/10.1016/j.rbe.2015.02.010.

Santos, M. M. M., Sucupira, I. M. C., Santos, T. V., Santos, A. C. F., Lacerda, R. N. L., Póvoa, M. M., 2019. Morphological identification of species of the Nuneztovari Complex of Anopheles (Diptera: Culicidae) from an area affected by a Brazilian hydroelectric plant. Zootaxa 4565 (2), 235-244. http://dx.doi.org/10.11646/zootaxa.4565.2.7.

Santos, R. L. C., Padilha, A., Costa, M. D. P., Costa, E. M., Dantas-Filho, H. C., Póvoa, M. M., 2009. Vetores de malária em duas reservas indígenas da Amazônia Brasileira. Rev. Saude Publica 43 (5), 859-868. http:// dx.doi.org/10.1590/S0034-89102009000500016.

Santos, R. L. C., Sucupira, I. M. C., Lacerda, R. N. L., Fayal, A. S., Póvoa, M. M., 2005. Inquérito entomológico e infectividade durante epidemia de malária no município de Anajás, Estado do Pará. Rev. Soc. Bras. Med. Trop. 38 (2), 202-204. http://dx.doi.org/10.1590/ S0037-86822005000200018.

Scarpassa, V. M., Geurgas, S., Azeredo-Espin, A. M. L., Tadei, W. P., 2000. Genetic divergence in mitochondrial DNA of Anopheles nuneztovari (Diptera, Culicidae) from Brazil and Colombia. Genet. Mol. Biol. 23 (1), 71-78.

Scarpassa, V. M., Tadei, W. P., Suarez, M. F., 1996. Allozyme differentiation among allopatric populations of Anopheles nuneztovari (Diptera, Culicidae). Braz. J. Genet. 19 (2), 265-269.

Schoeler, G. B., Flores-Mendoza, C., Fernández, R., Davila, J. R., Zyzak, M., 2003. Geographical distribution of Anopheles darlingi in the Amazon Basin region of Peru. J. Am. Mosq. Control Assoc. 19 (4), 286-296.

Service, M. W. 1993. Mosquitoes (Culicidae). In: Lane, R.P., Crosskey, R.W., eds. Medical Insects and Arachnids, Chapman \& Hall, London. http://dx.doi.org/10.1007/978-94-011-1554-4_5.

Silva, N. S., Silva-Nunes, M., Malafronte, R. S., Menezes, M. J., D’Arcadia, R. R., Komatsu, N. T., Scopel, K. K. G., Braga, E. M., Cavasini, C. E., Cordeiro, J. A., Ferreira, M. U., 2010. Epidemiology and control of frontier malaria in Brazil: lessons from community-based studies in rural Amazonia. Trans. R. Soc. Trop. Med. Hyg. 104 (5), 343-350. http://dx.doi.org/10.1016/j.trstmh.2009.12.010.

Silva-Vasconcelos, A., Kato, M. Y. N., Mourão, E. N., Souza, R. T. L., Lacerda, R. N. L., Sibajev, A., Tsouris, P., Póvoa, M. M., Momen, H., Rosa-Freitas, M. G., 2002. Biting indices, host-seeking activity and natural infection rates of anopheline species in Boa Vista, Roraima, Brazil from 1996 to 1998. Mem. Inst. Oswaldo Cruz 97 (2), 151-161. http://dx.doi.org/10.1590/S0074-02762002000200002.

Sinka, M. E., Rubio-Palis, Y., Manguin, S., Patil, A. P., Temperley, W. H., Gething, P. W., Van Boeckel, T., Kabaria, C. W., Harbach, R. E., Hay, S. I., 2010. The dominant Anopheles vectors of human malaria in the Americas: occurrence data, distribution maps and bionomic précis. Parasit. Vectors 3 (1), 72-98. http://dx.doi.org/10.1186/17563305-3-72.

Snounou, G., Viriyakosol, S., Zhu, X. P., Jarra, W., Pinheiro, L., Rosário, V. E., Thaithong, S., Brown, K. N., 1993. High sensitivy of detection of human malaria parasites by the use of nested polymerase chain reaction. Mol. Biochem. Parasitol. 61 (2), 315-320. http://dx.doi. org/10.1016/0166-6851(93)90077-B.

Tadei, W. P., 1987. Biologia de anofelinos Amazônicos XI. Estudos em populações de Anopheles e controle da malária em Ariquemes (Rondônia). Acta Amazon. 17 (1, Suppl.1), 151-167. http://dx.doi. org/10.1590/1809-43921987175167.

Tadei, W. P., Dutary-Thatcher, B., Santos, J. M., Scarpassa, V. M., Rodrigues, I. B., Rafael, M. S., 1998. Ecologic observations on anopheline vectors of malaria in the Brazilian Amazon. Am. J. Trop. Med. Hyg. 59 (2), 325-335. http://dx.doi.org/10.4269/ajtmh.1998.59.325.

Tadei, W. P., Rodrigues, I. B., Rafael, M. S., Sampaio, R. T. M., Mesquita, H. G., Pinheiro, V. C. S., Zequi, J. A. C., Roque, R. A., Santos, J. M. M., 2017. Adaptative processes, control measures, genetic background, and resilience of malaria vectors and environmental changes in the Amazon region. Hydrobiologia 789 (1), 179-196. http://dx.doi. org/10.1007/s10750-016-2960-y.

Tadei, W. P., Santos, J. M. M., Scarpassa, V. M., Rodrigues, I. B., 1993. Incidence, distribution and ecological aspects of Anopheles species (Diptera: Culicidae) in natural areas and environmental impact in the Brazilian Amazon. In: Ferreira, E.J.G., Santos, G.M., Leão, E.L.M., Oliveira, L.A. (Eds.), Bases científicas para estratégias de preservação e desenvolvimento da Amazônia. 1. ed. Instituto Nacional de Pesquisas da Amazônia, Manaus.

Tucker Lima, J. M., Vittor, A., Rifai, S., Valle, D., 2017. Does deforestation promote or inhibit malaria transmission in the Amazon? A systematic literature review and critical appraisal of current evidence. Philos. Trans. R. Soc. Lond. B Biol. Sci. 372 (1722), 20160125. http://dx.doi. org/10.1098/rstb.2016.0125.

Turell, J. M., Sardelis, M. R., Jones, J. W., Watts, D. M., Fernandez, R., Carbajal, F., Pecor, J. E., Klein, T. A., 2008. Seasonal distribution, biology, and human attraction patterns of mosquitoes (Diptera: Culicidae) in a rural village and adjacent forested site near Iquitos, Peru. J. Med. Entomol. 45 (6), 1165-1172. http://dx.doi.org/10.1093/ jmedent/45.6.1165.

Valente, M. A., Oliveira Junior, R. C., Rodrigues, T. E., Santos, P. L., Silva, J. M. L., Cardoso Junior, E. Q., 1998. Solos da Ilha de Santana, município da Santana, Estado do Amapá. Embrapa-CPATU, Belém.

Vittor, Y., Gilman, R. H., Tielsh, J., Glass, G., Shields, T., Sanchez-Lozano, W., Pinedo-Cancino, V. V., Patz, J. A., 2006. The effect of deforestation on the human biting rate of Anopheles darlingi, the primary vector of Plasmodium falciparum malaria in the Peruvian Amazon. Am. J. Trop. Med. Hyg. 74 (1), 3-11. http://dx.doi.org/10.4269/ajtmh.2006.74.3.

Voorham, J., 2002. Intra-population plasticity of Anopheles darlingi's (Diptera: Culicidae) biting activity patterns in the state of Amapá, Brazil. Rev. Saude Publica 36 (1), 75-80. http://dx.doi.org/10.1590/ S0034-89102002000100012.

White, M. T., Karl, S., Battle, K. E., Hay, S. I., Muelle, I., Ghani, A. C., 2014. Modelling the contribuition of the hypnozoite reservoir to Plasmodium vivax transmission. eLife 3, e04692. http://dx.doi. org/10.7554/eLife.04692.

World Health Organization - WHO, 2017. Immunization, Vaccines and Biologicals. Available in: http://www.who.int/vaccine_research/ links/Rainbow/en/index.html (accessed 17 July 2019).

World Health Organization - WHO, 2019. World Malaria Report 2019. WHO, Geneva.

World Health Organization - WHO, 2020. World Malaria Report 2020: 20 Years of Global Progress and Challenges. WHO, Geneva. 
Williams, J., Pinto, J., 2012. Manual de Entomologia de Malária: Para Técnicos de Entomologia e Controle de Vetores (Nível Básico). Agência dos Estados Unidos para o Desenvolvimento (USAID), RTI International. Williams, Y. A., Tusting, L. S., Hocini, S., Graves, P. M., Killeen, G. F., Kleinschmidt, I., Okumu, F. O., Feachem, R. G. A., Tatarsky, A., Gosling, R. D., 2018. Expanding the vector control toolbox for malaria elimination: a systematic review of the evidence. Adv. Parasitol. 99, 345-379. http://dx.doi.org/10.1016/bs.apar.2018.01.003.

Walter Reed Biosystematics Unit - WRBU, 2020. Systematic catalog of Culicidae Walter Reed Biosystematics Unit. Smithsonian Institution, Suitland. Available in: http://www.mosquitocatalog.org/ (accessed 04 June 2020). 


\section{Supplementary material}

The following online material is available for this article:

Table $1 \mathrm{~S}$ - Details of the methodology during the study, according to the collection categories, district of Ilha de Santana, municipality of Santana, state of Amapá. 